\title{
Discovery, properties and applications of chromium and its compounds
}

\author{
Hans-Joachim Lunk
}

Received: 4 December 2014 / Accepted: 16 January 2015/Published online: 13 February 2015

(C) Springer International Publishing 2015

\begin{abstract}
The basic properties of chromium are described, subsequently the discovery of chromium ores and the various methods of producing metallic chromium. How native chromium is formed and why the gemstone ruby has a connection to chromium are the following topics. The coordination of tri- and hexavalent chromium, hydrate isomerism, crystal field theory of $\mathrm{Cr}^{\mathrm{III}}$ and chromium(III)-containing polyoxotungstates as well as two fascinating redox reactions (breathalyzer, chemical volcano) are presented in the next sections. Then the focus is directed to various applications of metallic chromium and its compounds (metallurgy, dyes and pigments, wood preservatives, foundry, catalysis, tanning, interconnectors for SOFC). In conclusion, chromium's biological role and environmental concerns are discussed.
\end{abstract}

Keywords Metallic chromium - Discovery ·

Chromium compounds · Properties · Applications

\section{The properties of the transition-metal chromium}

A transition element or transition metal is any element in the d-block of the periodic table, which includes groups $3-$ 12. Chromium also belongs to the group of refractory metals, which comprises all metals with a higher melting point than platinum $\left(1,772{ }^{\circ} \mathrm{C}\right)$. The f-block lanthanide and actinide series are also considered transition metals and are called inner transition metals. Chromium (Fig. 1) is the 24th most abundant element in the earth crust; its basic properties are compiled in Table 1.

H.-J. Lunk $(\bowtie)$

2858 Lake Road, Towanda, PA 18848, USA

e-mail: baaclunk@epix.net
Naturally occurring chromium is composed of the three stable isotopes ${ }^{52} \mathrm{Cr},{ }^{53} \mathrm{Cr}$ and ${ }^{54} \mathrm{Cr}$ with ${ }^{52} \mathrm{Cr}$ being the most abundant $(83.8 \%)$. 19 radioisotopes have been characterized with the most stable being ${ }^{50} \mathrm{Cr}$ with a half-life of more than $1.8 \times 10^{17}$ years and ${ }^{51} \mathrm{Cr}$ with a half-life of 27.7 days. All of the remaining radioactive isotopes have half-lives that are less than $24 \mathrm{~h}$ and the majority of these have half-lives that are less than $1 \mathrm{~min} .{ }^{53} \mathrm{Cr}$ is the radiogenic decay product of ${ }^{53} \mathrm{Mn}$. Chromium isotopic contents are typically combined with manganese isotopic contents and have found application in isotope geology.

Thermal conductivity and expansion as well as Young's modulus of elasticity of chromium compared to that of molybdenum and tungsten as a function of temperature are presented in Figs. 2, 3, 4 (http://www.plansee.com/en/ Materials-Chromium-939.html).

\section{Early history and discovery of metallic chromium}

Chromium(III) oxide, $\mathrm{Cr}_{2} \mathrm{O}_{3}$, was used by the Chinese in the Qin Dynasty (秦朝, 259-210 B.C.E.) to coat weapons, such as bronze crossbow bolts and steel swords found at the Terracotta Army (Fig. 5). The Terracotta Army (also called Terracotta Warriors and Horses) is a collection of terracotta sculptures depicting the armies of Qin Shi Huang, the first Emperor of China. It is a form of funerary art buried with the emperor in 210-209 B.C.E. and whose purpose was to protect the emperor in his afterlife.

On July 26th, 1761, the German mineralogist and geologist Johann Gottlob Lehmann (1719-1767) (Fig. 6) found an orange-red mineral in the Beryozovskoye mines (Берёзовское месторождение) in the Ural Mountains which he named Siberian red lead. The mineral, 


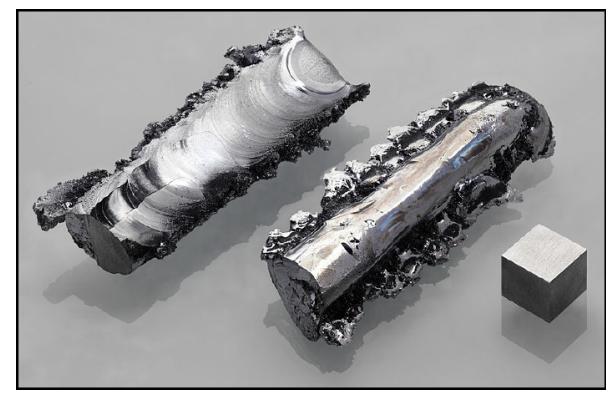

Fig. 1 Chromium, re-melted in an arc zone-refiner, showing large crystal grains

misidentified as a lead compound with selenium and iron components, is now known as Crocoite, $\mathrm{PbCrO}_{4}$ (Fig. 7).

The French pharmacist and chemist Louis-Nicolas Vauquelin (1763-1829) (Fig. 8) was convinced that the Siberian red lead contained a new element. In 1797, he won chromium(III) oxide, $\mathrm{Cr}_{2} \mathrm{O}_{3}$, from Crocoite. In 1798, he received contaminated elemental chromium by reduction of $\mathrm{Cr}_{2} \mathrm{O}_{3}$ with charcoal. The name of the element is derived from the Greek word "chrōma" ( $\chi \rho \omega ́ \mu \alpha)$, meaning color.

Eskolaite is a rare $\mathrm{Cr}_{2} \mathrm{O}_{3}$ mineral. It was first described in 1958 for an occurrence in the Outokumpu ore deposit of eastern Finland. The mineral is named after the Finnish geologist Pentti Eskola (1883-1964).

\section{Native chromium}

Although rare, deposits of elemental chromium exist. The Lucky Pipe (Трубка удачная) in Russia produced samples of the native metal. This mine is a kimberlite pipe, rich in diamonds. Kimberlite pipes are named after the town of Kimberly in South Africa, the site of the 'Big Hole', which

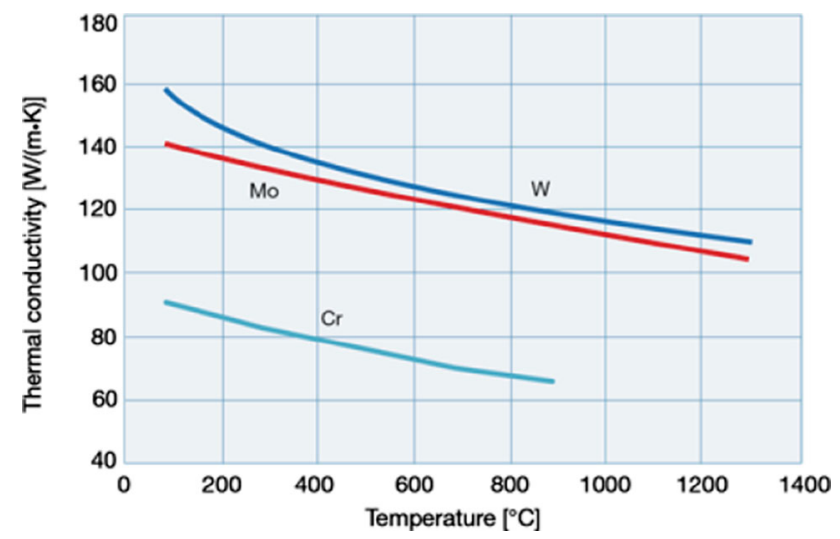

Fig. 2 Thermal conductivity $\left(\mathrm{W} \mathrm{m}^{-1} \mathrm{~K}^{-1}\right.$ )

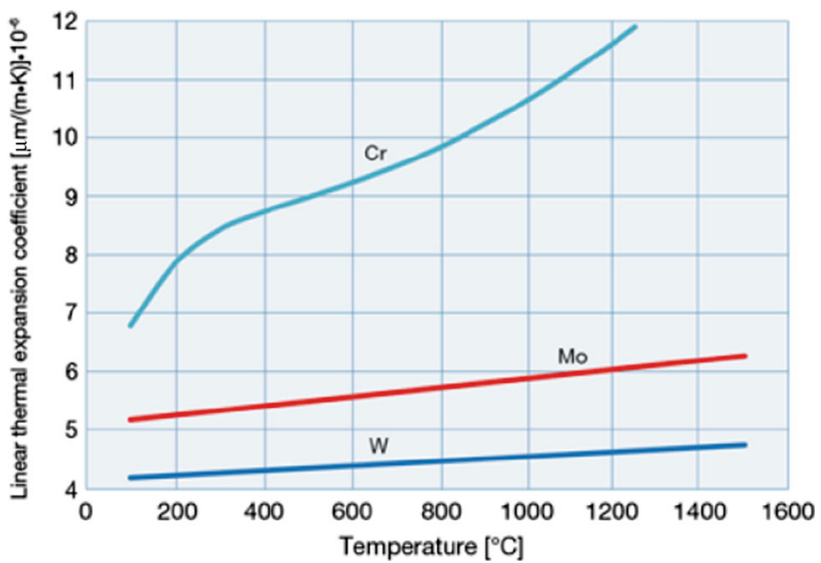

Fig. 3 Thermal expansion $\left(\mu \mathrm{m} \mathrm{m}^{-1} \mathrm{~K}^{-1}\right)$

is one of the largest mines excavated by hand, as well as the site of a major diamond rush at the turn of the last century. The reducing environment helped produce both elemental chromium and diamond. Figure 9 illustrates the

Table 1 Basic properties of chromium and its natural abundance

\begin{tabular}{|c|c|c|c|}
\hline Chromium in the periodic table & Atomic properties & Physical properties & Natural abundance $(\%)$ in \\
\hline $\begin{array}{l}\text { Atomic number } 24 \\
\text { Molar mass } 51.9961 \mathrm{~g} \mathrm{~mol}^{-1} \\
\text { Group 6; Period } 4 \\
\text { Electron configuration } \\
1 \mathrm{~s}^{2} 2 \mathrm{~s}^{2} 2 \mathrm{p}^{6} 3 \mathrm{~s}^{2} 3 \mathrm{p}^{6} 3 \mathrm{~d}^{5} 4 \mathrm{~s}^{1}\end{array}$ & $\begin{array}{l}\text { Electronegativity (Pauling scale) } 1.66 \\
\text { Ionization energies }\left(\mathrm{kJ} \mathrm{mol}^{-1}\right) \\
\text { 1st: } 652.9 \\
\text { 2nd: } 1,590.6 \\
\text { 3rd: } 2,987 \\
\text { Atomic radius } 128 \mathrm{pm} \\
\text { Covalent radius } 139 \pm 5 \mathrm{pm}\end{array}$ & $\begin{array}{l}\text { Crystal structure } \\
\text { Body-centered cubic (bcc) } \\
\text { Cell parameter } a \text { : } 291 \mathrm{pm} \\
\text { Melting point } 1,907{ }^{\circ} \mathrm{C} \\
\text { Boiling point } 2,671{ }^{\circ} \mathrm{C} \\
\text { Density } 7.19 \mathrm{~g} \mathrm{~cm}^{-3} \\
\text { Heat of fusion } \\
21.0 \mathrm{~kJ} \mathrm{~mol}^{-1} \\
\text { Heat of vaporization } \\
347 \mathrm{~kJ} \mathrm{~mol}^{-1} \\
\text { Molar heat capacity } \\
23.35 \mathrm{~J} \mathrm{~mol}^{-1} \mathrm{~K}^{-1}\end{array}$ & $\begin{array}{l}\text { Oceans } 6 \times 10^{-8} \\
\text { Humans } 3 \times 10^{-6} \\
\text { Universe } 1.5 \times 10^{-3} \\
\text { Sun } 2 \times 10^{-3} \\
\text { Earth's crust } 1.4 \times 10^{-2} \\
\text { Meteorites } 3 \times 10^{-1} \\
\text { Cr:Mo: } W=100: 1: 1\end{array}$ \\
\hline
\end{tabular}




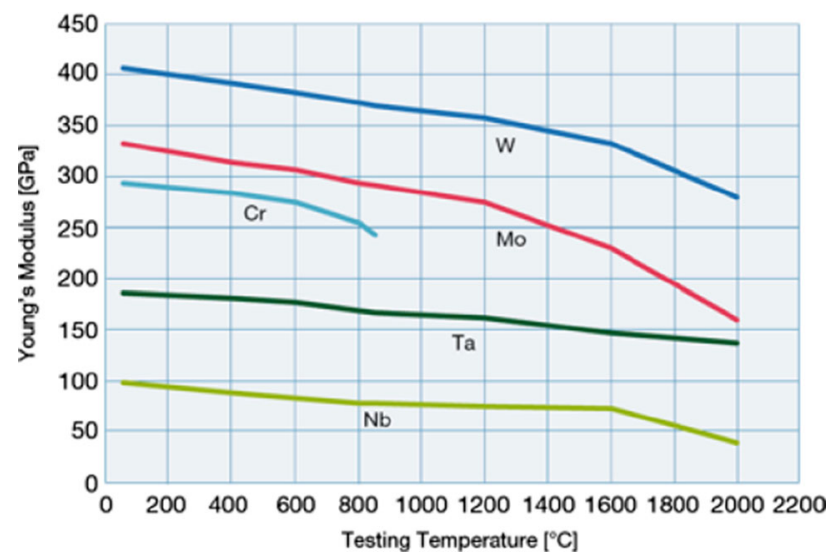

Fig. 4 Young's elasticity modulus (GPa)

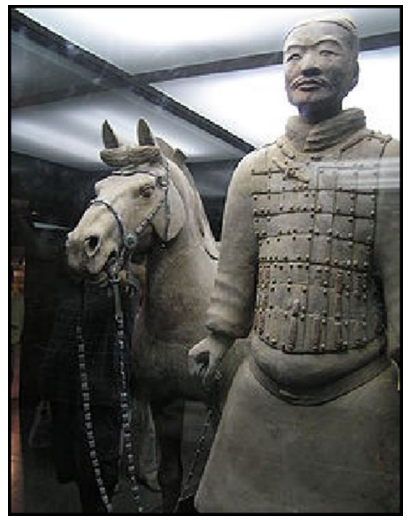

Fig. 5 Terracotta Army

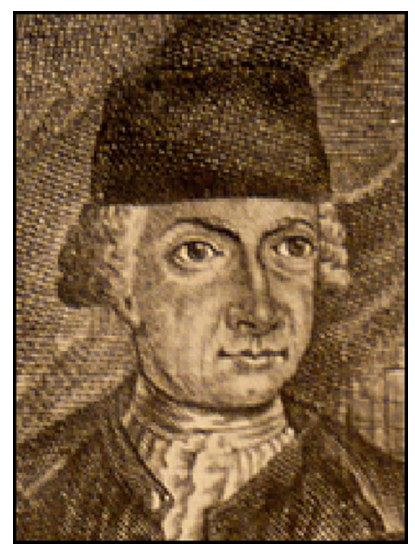

Fig. 6 Johann Gottlob Lehmann

classic South African model of a kimberlite pipe with old nomenclature (left side of Fig. 9) and a simpler, revised two-fold nomenclature system (right side). The Lucky Pipe (Fig. 10) is the largest diamond deposit in the DaldynAlakit kimberlite field in Jakutsk, the capital of Russia's largest Republic Jacutia [(Республика Саха (Якутия)] and

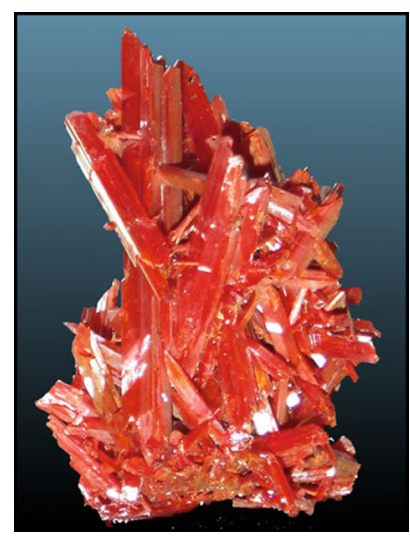

Fig. 7 Crocoite

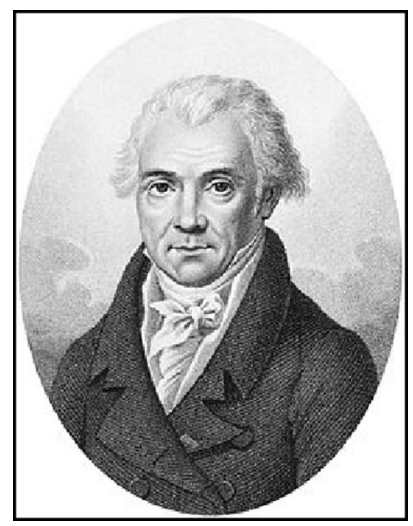

Fig. 8 Louis-Nicolas Vauquelin

one of the largest in the world. It is a more than $550 \mathrm{~m}$ deep open-pit mine located just outside the Arctic Circle.

\section{Ruby}

A ruby is a pink to blood-red colored gemstone, a variety of the mineral corundum ( $\alpha$-alumina), $\mathrm{Al}_{2} \mathrm{O}_{3}$, in which a small fraction of $\mathrm{Al}^{\mathrm{III}}$ is replaced by $\mathrm{Cr}^{\mathrm{III}}$. Ruby's name comes from ruber, Latin for red. Rubies have a hardness of 9.0 on the Mohs scale of mineral hardness. Ruby is considered one of the four precious stones, together with sapphire, emerald and diamond. Each $\mathrm{Al}^{\mathrm{III}}$ ion (and thus each $\mathrm{Cr}^{\mathrm{III}}$ ion) in the corundum crystal is surrounded by six oxide ions in a distorted octahedral coordination (Fig. 11). The red color is caused mainly by the presence of $\mathrm{Cr}^{\mathrm{III}}$. This crystallographic arrangement results in light absorption in the yellow-green region of the spectrum. When yellow-green light is absorbed, it is transmitted as red. The picture of a beautiful ruby is presented in Fig. 12. When the optical arrangement is such that the emission is stimulated by 694 $\mathrm{nm}$ photons reflecting back and forth between two mirrors, the emission grows strongly in intensity. This effect was 


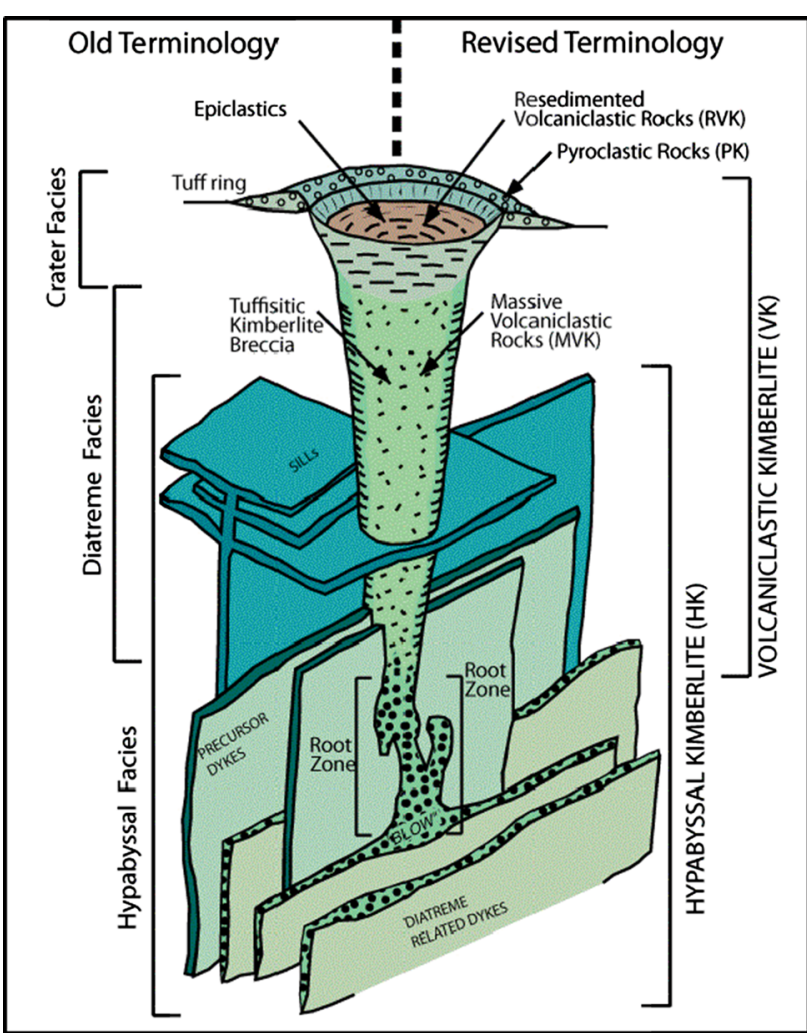

Fig. 9 Kimberlite pipe

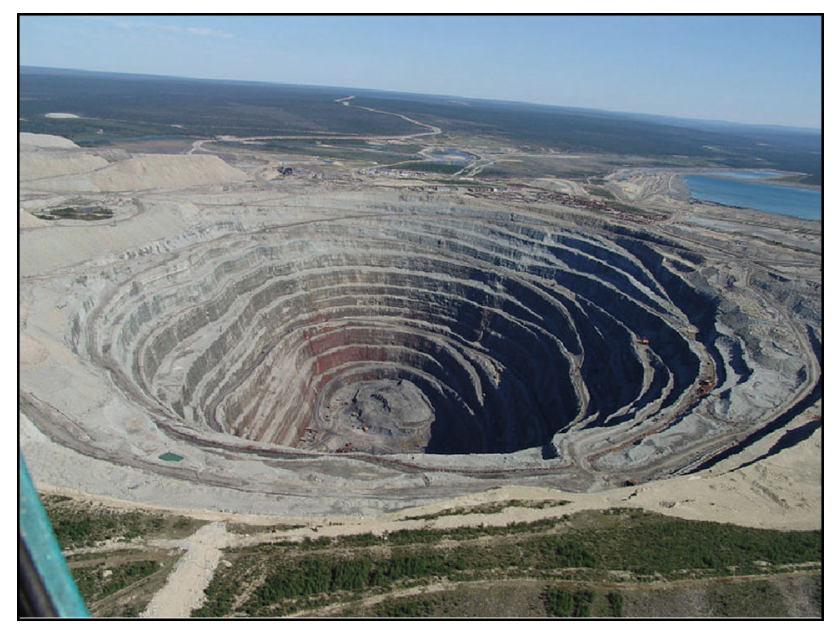

Fig. 10 Lucky pipe

used by Theodore Harold 'Ted' Maiman (1927-2007) in 1960 to make the first successful laser, based on ruby.

\section{Reduction of chromium(III) oxide}

Thermodynamic calculations

Using the program HSC 7.1 (http://www.chemistrysoftware.com/general/HSC_version7.html) the reducibility

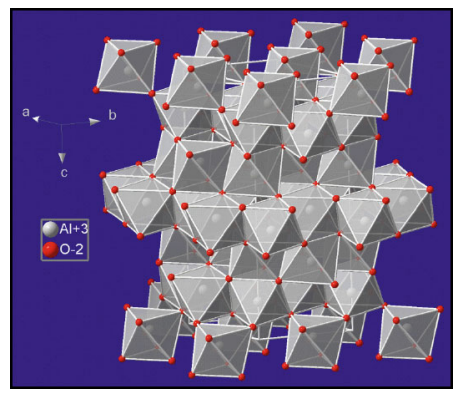

Fig. 11 Polyhedral model of corundum. $\mathrm{Al}^{\mathrm{III}}$ is sitting in $2 / 3$ of the octahedral sites

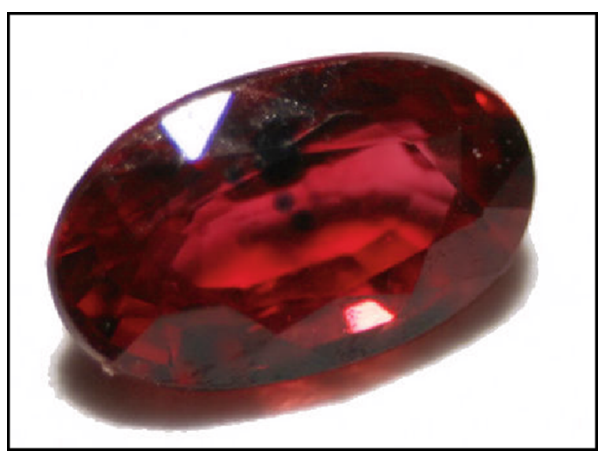

Fig. 12 Natural ruby with inclusions

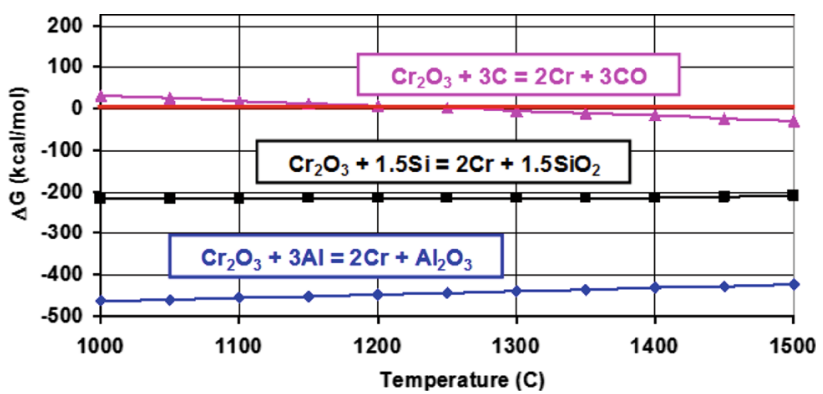

Fig. $13 \Delta G$ of alumino-, silico- and carbothermic reduction of $\mathrm{Cr}_{2} \mathrm{O}_{3}$

of chromium(III) oxide, $\mathrm{Cr}_{2} \mathrm{O}_{3}$, with aluminum, silicon, and carbon was evaluated (Fig. 13). Gibbs Free Energy change $\Delta G$ combines enthalpy change $\Delta H$ as well entropy change $\Delta S$ into a single value. The change of $\Delta G=\Delta H-T \Delta S$ can predict the direction of a chemical reaction under two conditions: (1) constant temperature and (2) constant pressure. If $\Delta G$ is positive, then the reaction is non-spontaneous (requires external energy to occur). If it is negative, then it is spontaneous (occurs without external energy input). The data for $\Delta G$ predict that-from the thermodynamic standpoint-aluminum and silicon are suitable reducing agents over a wide temperature range, while carbon needs temperatures $>1,200{ }^{\circ} \mathrm{C}$.

The ability of metals to participate in thermic reactions can also be predicted from Ellingham diagrams. An 
Ellingham diagram is a graph showing the temperature dependence of compounds' stability. This analysis is usually used to evaluate the ease of reduction of metal oxides and sulfides. The diagrams were first constructed by the British physical chemist Harold Johann Thomas Ellingham (1897-1975) in 1944. In metallurgy, the Ellingham diagram is used to predict the equilibrium temperature between a metal, its oxide and oxygen and-by extension - reactions of a metal with sulfur, nitrogen, and other nonmetals. The diagrams are useful in predicting the conditions under which an ore will be reduced to its metal. The analysis is thermodynamic in nature, and ignores reaction kinetics. Thus, processes that are predicted to be favorable by the Ellingham diagram can still be slow. The interactive Ellingham diagram is a teaching and learning tool, which can be used to obtain a variety of valuable thermodynamic information pertaining to a wide range of reactions. (http:// www.doitpoms.ac.uk/tlplib/ellingham_diagrams/interactive. html).

\section{Aluminothermic reduction}

The aluminothermic reduction (Aluminothermy) started from the experiments of the renowned Russian physical chemist Nikolay Nikolayevich Beketov (Николай Николаевич Бекетов) (1827-1911) (Fig. 14) at the University of Kharkov in Ukraine. Beketov executed the reduction of some metals from their oxides by means of aluminum at high temperatures, thus laying the basis of the aluminothermic process, which is now widely used in metallurgy. The reaction is highly exothermic, but it has a high activation energy since strong interatomic bonds in the solids must be broken first. The oxide was heated with aluminum in a crucible placed in a furnace. The runaway reaction made it possible to produce only small quantities of material.

Johannes ('Hans') Wilhelm Goldschmidt (1861-1923) (Fig. 15) improved the aluminothermic process between 1893 and 1898 by igniting a mixture of fine metal oxides and aluminum powder by a starter reaction (using e.g., magnesium ribbon) without heating the mixture externally. The process was patented in 1895 [1]. The legendary Robert Wilhelm Eberhard Bunsen (1811-1899) (Fig. 16) was Goldschmidt's doctoral adviser at Friedrich-WilhelmsUniversität (since 1949 Humboldt-Universität zu Berlin). His father, Theodor Goldschmidt (1817-1875), was the founder of the company Chemische Fabrik Th. Goldschmidt which eventually became part of the company Degussa. Hans and his older brother Karl managed their father's company for many years.

Thermite is a pyrotechnic composition of metal powder, fuel and metal oxide. When ignited by heat, thermite undergoes an exothermic redox (reduction-oxidation) reaction.

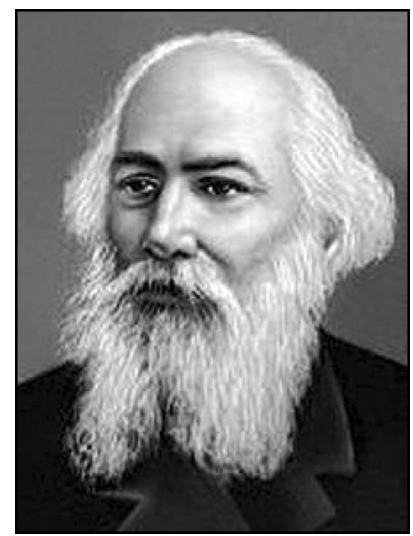

Fig. 14 Nikolay Nikolayevich Beketov

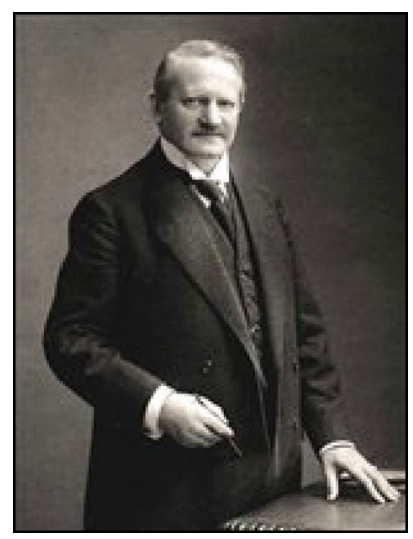

Fig. 15 'Hans' Wilhelm Goldschmidt

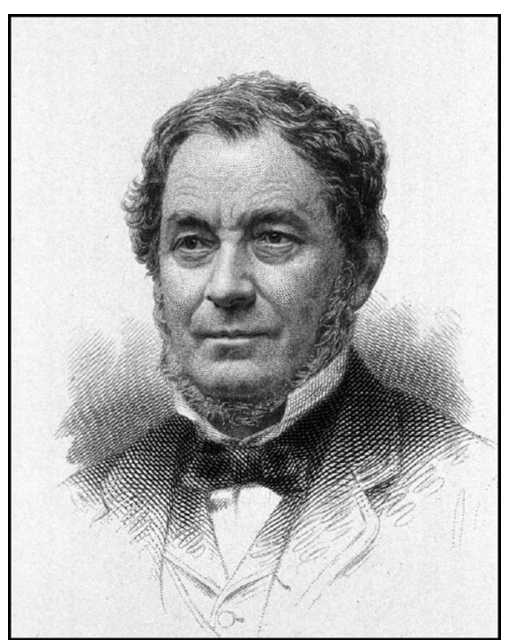

Fig. 16 Robert Wilhelm Eberhard Bunsen

Most varieties are not explosive but can create brief bursts of high temperature in a small area. Thermites have diverse compositions. Fuels include aluminum, magnesium, titanium, zinc, silicon, and boron. Aluminum is common because 


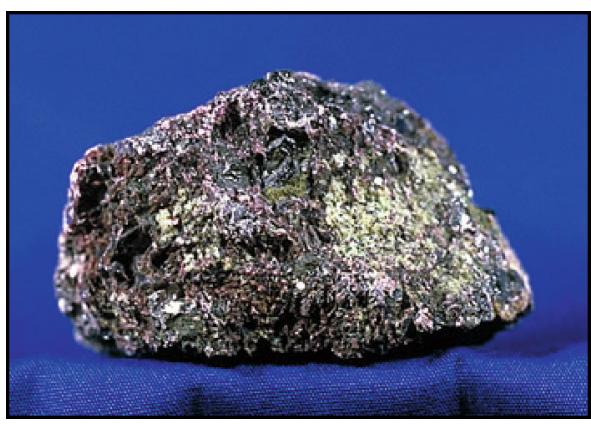

Fig. 17 Chromite

of its high boiling point of $2,470{ }^{\circ} \mathrm{C}$. Oxidizers include boron(III) oxide, silicon(IV) oxide, chromium(III) oxide $\left(\mathrm{Cr}_{2} \mathrm{O}_{3}+2 \mathrm{Al} \rightarrow 2 \mathrm{Cr}+\mathrm{Al}_{2} \mathrm{O}_{3}\right)$, manganese(IV) oxide, iron (III) oxide $\left(\mathrm{Fe}_{2} \mathrm{O}_{3}+2 \mathrm{Al} \rightarrow 2 \mathrm{Fe}+\mathrm{Al}_{2} \mathrm{O}_{3}\right)$, iron(II,III) oxide, copper(II) oxide, and lead(II,IV) oxide. Thermites have been used for welding metal parts such as railway rails, in metal refining, demolition of munitions, and in incendiary weapons.

Chromium is mined as chromite, $\mathrm{FeCr}_{2} \mathrm{O}_{4}$ (Fig. 17), the single commercially viable ore. In 2009, its world production accounted for 18.9 metric tons. About two-fifth of the ores and concentrates in the world are produced in South Africa, while Kazakhstan, India, Russia, and Turkey are also substantial manufacturers. Chromite, soda, and lime are mixed and heated in air at $1,100{ }^{\circ} \mathrm{C}$. The created calcine contains sodium monochromate, $\mathrm{Na}_{2} \mathrm{CrO}_{4}$, which is leached from the insoluble gangue, then reduced and precipitated as $\mathrm{Cr}_{2} \mathrm{O}_{3}$, blended with finely divided aluminum powder, charged to a refractory-lined container, and ignited. The combustion quickly generates temperatures in excess of $2,000{ }^{\circ} \mathrm{C}$, giving a clean separation of chromium from the slag. The purity of the metal, varying from 97 to $99 \%$ chromium, depends on the starting materials.

\section{Silicothermic reduction}

The production of metals and alloys by the reduction of ores or concentrates of metal oxides with silicon is based on the high affinity of silicon to oxygen. Silicothermic processes are carried out in arc furnaces, since the heat released upon reduction is not sufficient for melting or for the required heating of smelted products. The silicon used in these processes is usually in high-silicon alloy form, such as ferrosilicon, silicomanganese, and ferrochrome-silicon.

The silicothermic process is used in obtaining ferroalloys and hardeners with a low carbon content for use in the smelting of high-grade steels. Silicon interacts with many metals to form strong chemical compounds called silicides, which makes the reduction reaction more complete. This makes it possible to use the silicothermic method to reduce the oxides of calcium, magnesium, zirconium, and rareearth elements-a process otherwise difficult to achieve. The alloys obtained have always high silicon content.

\section{Carbothermic reduction}

Carbothermic reactions involve the reduction of substances, often metal oxides, using carbon as the reducing agent. These reactions are usually conducted at high temperatures. Such processes are applied for production of the elemental form of many elements. The ability of metals to participate in carbothermic reactions can be predicted from Ellingham diagrams (cf. section Thermodynamic calculations).

Carbothermic reactions produce carbon monoxide and sometimes carbon dioxide. The feasibility of these conversions is attributable to the reaction entropy: two solids, the metal oxide and carbon, are converted to a new solid (metal) and a gas (CO), the latter having high entropy. Heat is required for carbothermic reactions because diffusion of the reacting solids is slow otherwise. For some metals, carbothermic reactions do not afford the metal, but instead produce metal carbides. Carbides also form upon high temperature treatment of $\mathrm{Cr}_{2} \mathrm{O}_{3}$ with carbon. Therefore, aluminum is the preferred reducing agent for the production of chromium.

The kinetics of formation of $\mathrm{Cr}_{3} \mathrm{C}_{2}$ by the carbothermic reduction of $\mathrm{Cr}_{2} \mathrm{O}_{3}$ with graphite was studied in the temperature range $1,188-1,466{ }^{\circ} \mathrm{C}$ [2]. The experiments were carried out in a high vacuum chamber with the mechanically mixed reactants in pellet form, compacted at different pressures. The progress of the reaction was followed by monitoring the evolved $\mathrm{CO}$ gas with a quadrupole mass spectrometer. From the parabolic nature of the rate equation and the dependence of the activation energy of the reaction on the compaction pressure of the pellets, it was concluded that the diffusion of $\mathrm{CO}$ gas through the product layer is the rate-controlling step.

The isothermal carbothermic reduction of $\mathrm{Cr}_{2} \mathrm{O}_{3}$ was studied by XRD (X-ray diffraction), EDS (Energy-dispersive X-ray spectroscopy) and SEM (Scanning electron microscopy) [3]. Using a moderate carrier gas flow rate and fine graphite particles, the reduction rate increased with rising temperature. At $1,400{ }^{\circ} \mathrm{C}$, the chromium carbides $\mathrm{Cr}_{3} \mathrm{C}_{2}, \mathrm{Cr}_{7} \mathrm{C}_{3}, \mathrm{Cr}_{23} \mathrm{C}_{6}$ and $\mathrm{Cr}$ were formed. It was confirmed that the reduction contains various kinds of reactions, such as direct and indirect reduction of $\mathrm{Cr}_{2} \mathrm{O}_{3}$, the carbon solution-loss reaction and the reaction of chromium carbides with $\mathrm{CO}_{2}$. At the initial reduction stage, the direct reduction dominates the reduction rate. At the later stage, because of the chromium carbide layer formed on the surface of graphite particles and rather slow reduction rate, the ratecontrolling step is deduced to be $\mathrm{CO}$ and $\mathrm{CO}_{2}$ gas diffusion through the layer of reduction products. 
Fig. 18 SEM graphs of chromium powders

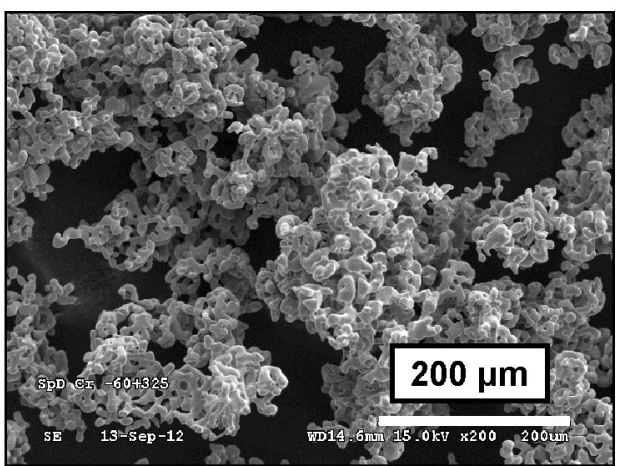

Tap density $1.2 \mathrm{~g} \mathrm{~cm}^{-3}$

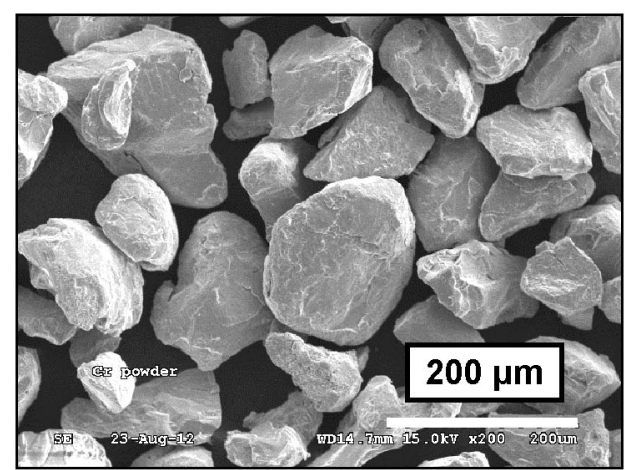

Tap density $4.1 \mathrm{~g} \mathrm{~cm}^{-3}$
SEM graphs of two chromium powders with different grain sizes and tap densities are shown in Fig. 18.

\section{Electrolytic reduction}

Chromium metal was made through electrolysis in 1854 by Robert Bunsen (cf. section Aluminothermic reduction), but this method did not find wide acceptance until a century later. In the commercial electrolytic process, chromium alum (cf. Fig. 30), i.e., potassium chromium(III) sulfate dodecahydrate, $\mathrm{KCr}\left(\mathrm{SO}_{4}\right)_{2} \cdot 12 \mathrm{H}_{2} \mathrm{O}$, is dissolved in hot water and fed into the cathode portion of an electrolytic cell. The cell is divided by a diaphragm to prevent the chromic and sulfuric acids formed at the anode from mixing with the catholyte (cathode electrolyte). With the passage of electric current from a lead anode to a thin stainless-steel cathode sheet, chromium is plated onto the cathode and is stripped from the sheet every $72 \mathrm{~h}$, sealed in stainless steel cans, and heated to $420{ }^{\circ} \mathrm{C}$ to remove water and hydrogen. This electrolytic chromium contains $0.5 \%$ oxygen, which is too high for some applications. Combining it with carbon and heating the briquettes to $1,400{ }^{\circ} \mathrm{C}$ at $13 \mathrm{~Pa}(0.1$ Torr) lowers the oxygen content to $0.02 \%$, resulting in a metal more than $99.9 \%$ pure. In view of the severe regulations for environmental pollution, it has become more difficult to produce metallic chromium in this way economically. Japan has already ceased the production of electrolytic chromium by March 1995.

\section{Chromium's oxidation states}

Chromium exhibits a wide range of oxidation states from -4 to +6 , where the +3 state is most stable energetically. The +3 and +6 states are most commonly observed in chromium compounds. A few prominent examples are shown in Table 2 . The oxidation states $+1,+2,+4$ and +5 are relatively rare, realized e.g. in the compounds $\mathrm{K}_{3}\left[\mathrm{Cr}(\mathrm{CN})_{5} \mathrm{NO}\right](+1), \mathrm{CrCl}_{2}(+2), \mathrm{K}_{2} \mathrm{CrF}_{6}(+4)$ and
Table 2 Examples of chromium compounds with oxidation states +3 and +6

\begin{tabular}{lll}
\hline $\begin{array}{l}\text { Oxidation } \\
\text { state }\end{array}$ & Compounds & Sample \\
\hline+3 & $\mathrm{CrCl}_{3}$ Chromium(III) chloride \\
& \\
& $\begin{array}{l}{\left[\mathrm{CrCl}_{2}\left(\mathrm{OH}_{2}\right)_{4}\right] \mathrm{Cl} \cdot 2 \mathrm{H}_{2} \mathrm{O}} \\
\text { Dichlorotetraaquachromium(III) } \\
\text { chloride dihydrate } \\
+6\end{array}$ & $\mathrm{~K}_{2} \mathrm{CrO}_{4}$ Potassium monochromate \\
& \\
& $\mathrm{K}_{2} \mathrm{Cr}_{2} \mathrm{O}_{7}$ Potassium dichromate \\
& \\
\hline
\end{tabular}

$\mathrm{K}_{3} \mathrm{CrO}_{4}(+5)$. The oxidation states $-4,-3,-2,-1$ and 0 are very rare; examples are $\left[\mathrm{Cr}(\mathrm{CO})_{4}\right]^{4-}(-4),\left[\mathrm{Cr}(\mathrm{bpy})_{3}\right]^{3-}$ $(-3), \quad \mathrm{Na}_{2}\left[\mathrm{Cr}(\mathrm{CO})_{5}\right] \quad(-2), \quad \mathrm{Na}_{2}\left[\mathrm{Cr}_{2}(\mathrm{CO})_{10}\right] \quad(-1)$ and $\mathrm{Cr}\left(\mathrm{C}_{6} \mathrm{H}_{6}\right)_{2}(0)$.

\section{Coordination of tri- and hexavalent chromium}

Aquacomplexes of chromium(III)

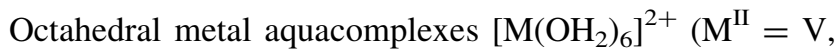
$\mathrm{Cr}, \mathrm{Mn}, \mathrm{Fe}, \mathrm{Co}, \mathrm{Ni}, \mathrm{Cu})$ and $\left[\mathrm{M}\left(\mathrm{OH}_{2}\right)_{6}\right]^{3+}\left(\mathrm{M}^{\mathrm{III}}=\mathrm{Ti}, \mathrm{V}\right.$, $\mathrm{Cr}, \mathrm{Fe}$ ) are most common. Only a few aquacomplexes exist with coordination numbers lower than six. Solutions of metal aquacomplexes are acidic owing to the ionization of protons from the water ligands. Hence, in dilute solution the chromium(III) aquacomplex has an acidity constant $\left(\mathrm{p} K_{\mathrm{a}}\right)$ of about 4.3 :

$\left[\mathrm{Cr}\left(\mathrm{OH}_{2}\right)_{6}\right]^{3+}+\mathrm{H}_{2} \mathrm{O} \rightleftarrows\left[\mathrm{Cr}\left(\mathrm{OH}_{2}\right)_{5}(\mathrm{OH})\right]^{2+}+\mathrm{H}_{3} \mathrm{O}^{+}$ 


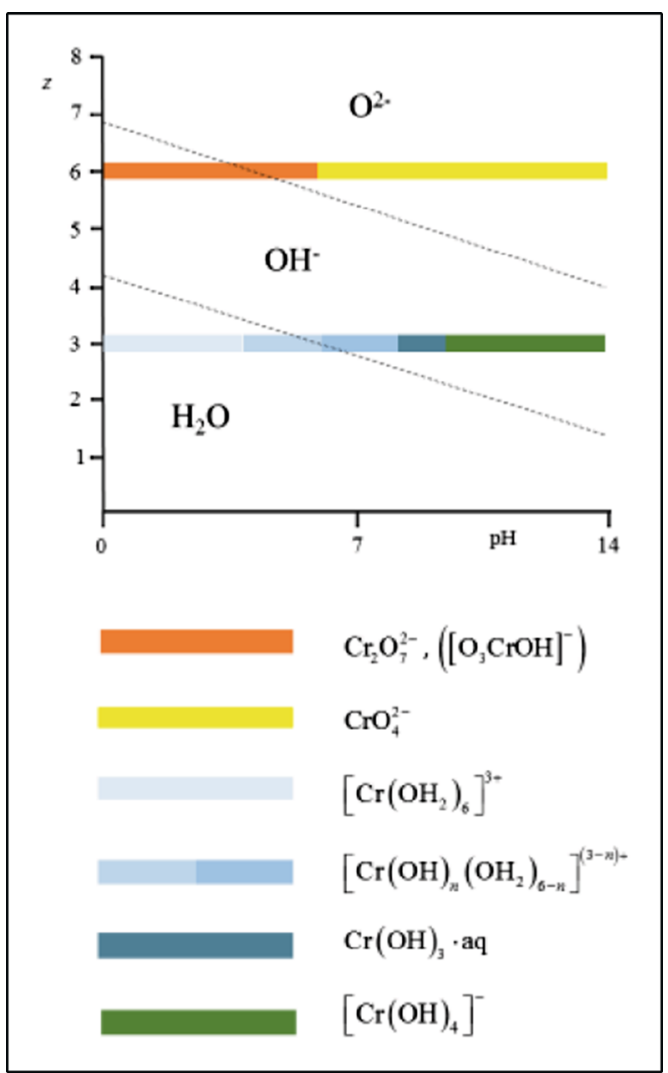

Fig. $19 \mathrm{pH}$ ranges for $\mathrm{H}_{2} \mathrm{O}, \mathrm{OH}^{-}$and $\mathrm{O}^{2-}$ as ligands of $\mathrm{Cr}^{\mathrm{III}}$ and $\mathrm{Cr}^{\mathrm{VI}}$ (Adopted from [4])

The diagram (Fig. 19) illustrates the approximate predominance areas of the ligands $\mathrm{H}_{2} \mathrm{O}, \mathrm{OH}^{-}$and $\mathrm{O}^{2-}$ in metal complexes as a function of the oxidation state $z$ of the non-coordinated metal ion $\left(\mathrm{M}^{\mathrm{n}+}\right)$ and the solution's $\mathrm{pH}$. Chromium(III) and chromium(VI) species are shown as examples.

At low $\mathrm{pH}$ values the hexaaquachromium(III) cation $\left[\mathrm{Cr}\left(\mathrm{OH}_{2}\right)_{6}\right]^{3+}$ (light blue) is present. With increasing $\mathrm{pH}$ initially two hydroxoaquachromium(III) cations $\left[\mathrm{Cr}(\mathrm{OH})_{n}\left(\mathrm{OH}_{2}\right)_{6-n}\right]^{(3-n)+}(n=1,2)$ (blue) are predominant, subsequently the amphoteric chromium(III) hydroxide $\mathrm{Cr}(\mathrm{OH})_{3}$.aq (gray blue precipitate) and finally the tetrahydroxochromate(III) anion $\left[\mathrm{Cr}(\mathrm{OH})_{4}\right]^{-}$(green).

At $25^{\circ} \mathrm{C}$, the water exchange rates of $\left[\mathrm{Cr}\left(\mathrm{OH}_{2}\right)_{6}\right]^{3+}$ and $\left[\mathrm{Cr}\left(\mathrm{OH}_{2}\right)_{6}\right]^{2+}$ differ dramatically, namely $2.4 \times 10^{-6} \mathrm{~s}^{-1}$ versus $1.2 \times 10^{8} \mathrm{~s}^{-1}$. Due to the extremely slow ligand exchange rates of all $\mathrm{Cr}^{\mathrm{III}}$ aquacomplexes, containing as ligands in addition to $\mathrm{H}_{2} \mathrm{O}$ e.g. $\mathrm{Cl}^{-}$or $\mathrm{SO}_{4}{ }^{2-}$, it is virtually impossible to prepare complexes which contain only the monomeric chromium hexaaquachromium(III) cation, $\left[\mathrm{Cr}\left(\mathrm{OH}_{2}\right)_{6}\right]^{3+}$. Such solutions can, however, be synthesized by reduction of chromic acid, $\mathrm{CrO}_{3}$ (cf. section Further applications) with hydrogen peroxide, $\mathrm{H}_{2} \mathrm{O}_{2}$, in perchloric acid, $\mathrm{HClO}_{4}$ [5]. The UV spectrum indicated that no oligomers are present in this solution [6].
Hydrate isomerism of $\mathrm{CrCl}_{3} \cdot 6 \mathrm{H}_{2} \mathrm{O}$

Hydrate (in general solvate) isomers (literally 'equal parts') have the identical overall composition but differ with respect to the number of hydrate (solvent) ligand molecules as well as the counter ions in the crystal lattice. The three hydrate isomers of the salt $\mathrm{CrCl}_{3} \cdot 6 \mathrm{H}_{2} \mathrm{O}$ relate to $\left[\mathrm{CrCl}_{3-n}\left(\mathrm{OH}_{2}\right)_{3+n}\right]^{n+}(n=1,2,3)$. The predominant hexahydrate is the dark-green dichlorotetraaquachromium (III) chloride dihydrate, $\left[\mathrm{CrCl}_{2}\left(\mathrm{OH}_{2}\right)_{4}\right] \mathrm{Cl} \cdot 2 \mathrm{H}_{2} \mathrm{O}$ (cf. Table 2). It consists of the cation trans- $\left[\mathrm{CrCl}_{2}\left(\mathrm{OH}_{2}\right)_{4}\right]^{+}$ and two additional water molecules as well as a chloride anion in the lattice. The two other hydrates are the pale green chloropentaaquachromium(III) chloride hydrate, $\left[\mathrm{CrCl}\left(\mathrm{OH}_{2}\right)_{5}\right] \mathrm{Cl}_{2} \cdot \mathrm{H}_{2} \mathrm{O}$ and the violet hexaaquachromium(III) chloride, $\left[\mathrm{Cr}\left(\mathrm{OH}_{2}\right)_{6}\right] \mathrm{Cl}_{3}$.

Crystal field theory of chromium(III)

The $\mathrm{d}$ electron count is a formalism used to describe the electron configuration of the valence electrons of a transition metal in a coordination complex. It is an effective way to understand geometry, magnetism and reactivity of transition metal complexes. The formalism has been incorporated into the two major models used to describe these complexes, Crystal Field Theory (CFT) and Ligand Field Theory (LFT).

CFT was developed in 1929 by the physicist Hans Bethe (1906-2005). CFT defines the interaction between a central metal ion that is surrounded by anions and/or molecules. A quantum mechanical description of the metal ion is employed, with attention focused on the valence shell orbitals. The surrounding ligands are typically treated as point charges. If the ligand is negatively charged, a cation-anion interaction is present. In the case of a neutral ligand, there is a cation-dipole interaction. The geometry of the negatively charged ligands influences the energy levels of the central metal ion. The CFT was further developed by John Hasbrouck van Vleck (1899-1980) in 1935 to allow for some covalence in the interactions. These modifications are often referred to as LFT.

The CFT for the $\mathrm{d}^{3}$ ion $\mathrm{Cr}^{\mathrm{III}}$ (electron configuration [Ar] $3 \mathrm{~d}^{3}$ ) will be discussed in the following. As the result of the threefold ionization of metallic chromium (cf. Table 1) three electrons from the orbital with the highest principle quantum number had been removed. As a simplification, we assume that $\mathrm{Cr}^{\mathrm{III}}$ exists in a perfect octahedral coordination. The five 'conventional real (or directed)' [7] 3d orbitals split into two groups: $t_{2 g}\left(3 \mathrm{~d}_{\mathrm{xy}}, 3 \mathrm{~d}_{\mathrm{xz}}, 3 \mathrm{~d}_{\mathrm{yz}}\right)$ at lower and $e_{g}\left(3 \mathrm{~d}_{\mathrm{x} 2-\mathrm{y} 2}, 3 \mathrm{~d}_{\mathrm{z} 2}\right)$ at higher energy (Fig. 20). For $\mathrm{d}^{1}-\mathrm{d}^{3}$ systems the Hund's rule predicts that the three electrons will not pair, but occupy the $t_{2 g}$ set with spin up (spin quantum number $+1 / 2$ ). The corresponding ground-state 
Fig. 20 The five $3 \mathrm{~d}$ orbitals. The surfaces shown enclose $90 \%$ of the total electron probability

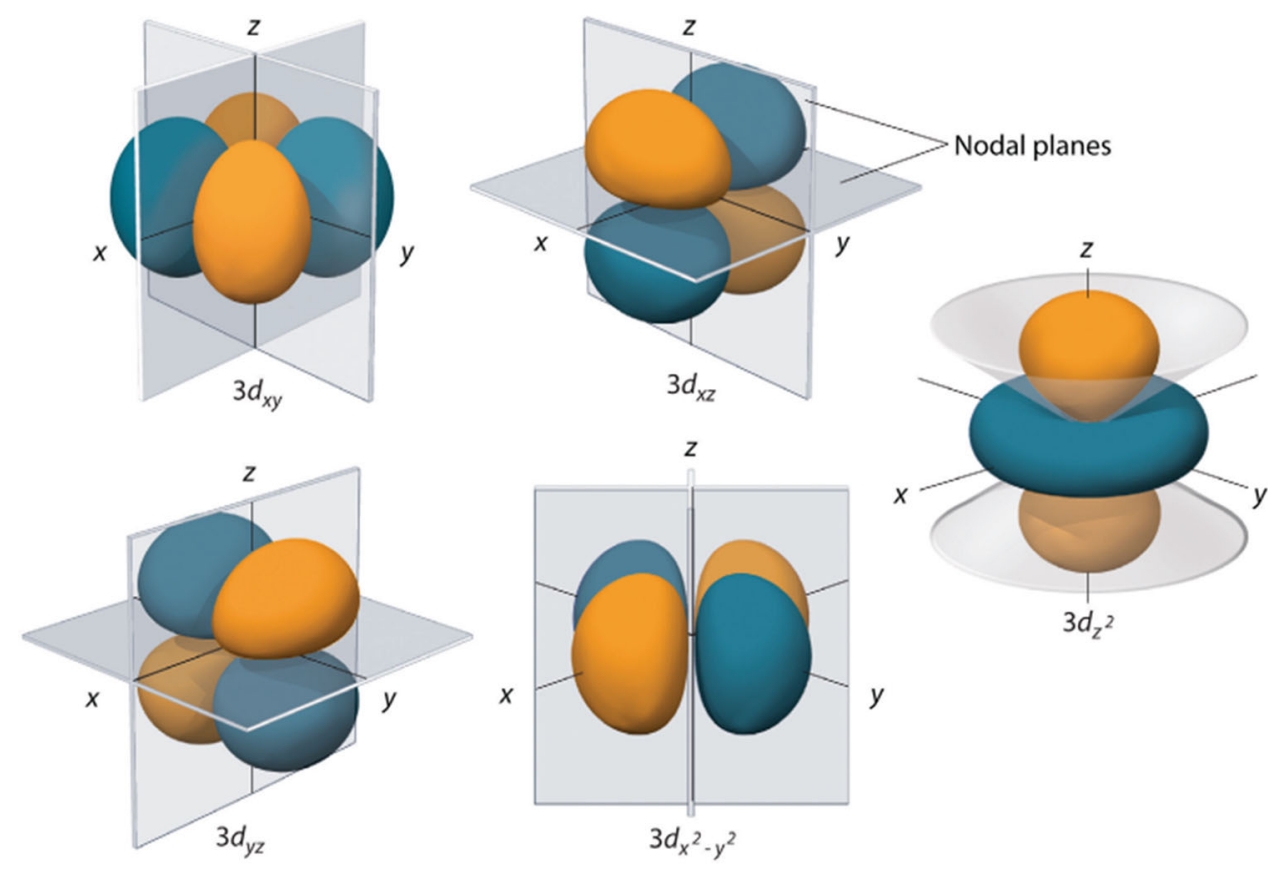

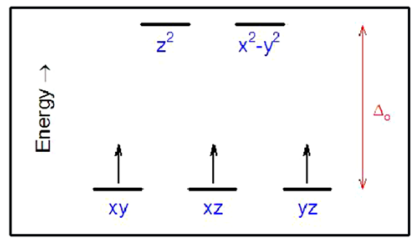

Fig. $21 \mathrm{Cr}^{\mathrm{III}}$ ground-state electron configuration in octahedral coordination

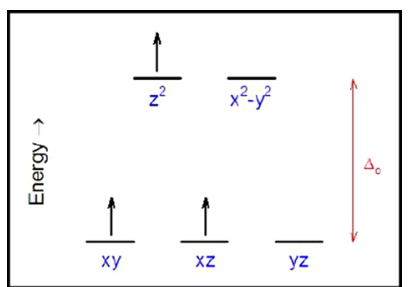

Fig. $22 \mathrm{Cr}^{\mathrm{III}}$ excited-state electron configuration in octahedral coordination

electron configuration in octahedral coordination is shown in Fig. 21.

If a photon with the energy $\Delta_{o}$ strikes $\mathrm{Cr}^{\mathrm{III}}$, it can be absorbed and an electron will be promoted from the lowlying orbital set $t_{2 g}$ to the high-lying set $e_{g}$. The electron configuration of the excited state is shown in Fig. 22. Given that the orbitals $3 \mathrm{~d}_{\mathrm{xy}}, 3 \mathrm{~d}_{\mathrm{xz}}$, and $3 \mathrm{~d}_{\mathrm{yz}}$ are equivalent, thus the electron may be removed from any of these orbitals. The orbitals $3 \mathrm{~d}_{\mathrm{x} 2-\mathrm{y} 2}$, and $3 \mathrm{~d}_{\mathrm{z} 2}$ are also equivalent, thus the promoted electron may be placed in either of these two orbitals. The photon energy $\Delta_{o}$ can be calculated in different ways: $\Delta_{o}=h \times v=h \times c \times \lambda^{-1}=h \times c \times k$ (Planck's constant $h=6.62608 \times 10^{-34} \mathrm{~J} \mathrm{~s}$, frequency of the light $v$, light velocity $c=2.997925 \times 10^{10} \mathrm{~cm} \mathrm{~s}^{-1}$, wavelength $\lambda$, wavenumber $k$ ). The complex $\left[\mathrm{Cr}\left(\mathrm{OH}_{2}\right)_{6}\right]^{3+}$ absorbs light in the yellow range of the visible spectrum $(400-800 \mathrm{~nm})$ with a maximum at $\lambda=561 \mathrm{~nm}\left(k=17,830 \mathrm{~cm}^{-1}\right)$. As a consequence, its solution appears violet. The absorption may be measured using a spectrophotometer and displayed as an absorption spectrum. Using the wavenumber for the $t_{2 g} \rightarrow e_{g}$ transition of $17,830 \mathrm{~cm}^{-1}, \Delta_{o}$ is calculated to $3.54 \times 10^{-19} \mathrm{~J} \triangleq 213 \mathrm{~kJ} \mathrm{~mol}^{-1}$. Typical $\Delta_{o}$ values are of the same range as chemical bond energies.

More details about CFT can be found in http://www. chem.iitb.ac.in/ rmv/ch102/cft.pdf, http://www.chm.david son.edu/vce/coordchem/splitting.html and in Textbooks of Theoretical Chemistry.

Chromium(III)-containing polyoxotungstates

Polyoxometalates (POMs) are an important class of inorganic compounds that are of both theoretical and practical interest [8]. In 1826 Jöns Jacob Berzelius (1779-1848) prepared the first polyoxomolybdate by adding ammonium paramolybdate, $\left[\mathrm{NH}_{4}\right]_{6}\left[\mathrm{Mo}_{7} \mathrm{O}_{24}\right] \cdot 4 \mathrm{H}_{2} \mathrm{O}$, to phosphoric acid, $\mathrm{H}_{3} \mathrm{PO}_{4}$. More than 100 years later, in 1933, James Keggin threw light on the structure of this compound by his groundbreaking single-crystal X-ray study. During the following decades, a vast variety of POMs with molybdenum, tungsten or vanadium as 'poly'atom and different 'hetero'atoms were synthesized. The polyhedral model of 


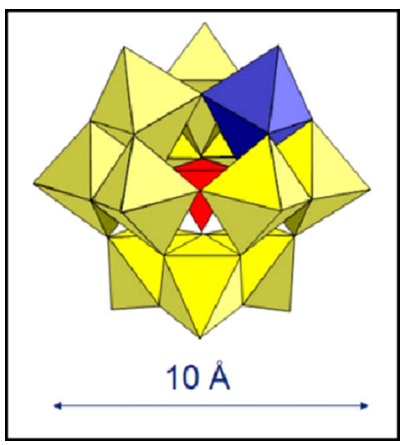

Fig. 23 Polyhedral model of the Keggin anions $\left[\alpha-\mathrm{XO}_{4} \mathrm{~W}_{12} \mathrm{O}_{36}\right]^{(8-\mathrm{x})-}$ and $\left[\alpha-\mathrm{XO}_{4} \mathrm{~W}_{11} \mathrm{O}_{35}\right]^{(12-\mathrm{x})-}$

the famous Keggin anion $\left[\alpha-\mathrm{XO}_{4} \mathrm{~W}_{12} \mathrm{O}_{36}\right]^{(8-\mathrm{x})^{-}}(\mathrm{X}=\mathrm{B}, \mathrm{Al}$, $\mathrm{Ga}, \mathrm{C}, \mathrm{Si}, \mathrm{Ge}, \mathrm{P}^{\mathrm{V}}, \mathrm{As}^{\mathrm{V}}, \mathrm{Fe}^{\mathrm{III}}, \mathrm{Co}^{\mathrm{II}}, \mathrm{Co}^{\mathrm{III}} . \mathrm{Cu}^{\mathrm{II}}, \mathrm{Zn}$; $\mathrm{x}$ : oxidation state of $\mathrm{X}$ ) is shown in Fig. 23. The anion is built by $12 \mathrm{WO}_{6}$ octahedra, which surround the central tetrahedrally coordinated 'heteroatom' X. Four edge-linked $\mathrm{W}_{3} \mathrm{O}_{13}$ groups are connected over corners. The anion $\left[\alpha-\mathrm{XO}_{4} \mathrm{~W}_{11} \mathrm{O}_{35}\right]^{(12-\mathrm{x})-}(\mathrm{X}=\mathrm{B}, \mathrm{Si}, \mathrm{Ge}, \mathrm{P}, \mathrm{As})$, known as 'lacunar' arrangement, derives from the complete Keggin structure by removing a $\mathrm{W}=\mathrm{O}$ group (highlighted in blue). By removing two or three $\mathrm{W}=\mathrm{O}$ groups from the intact Keggin anion the divacent and trivacent entities are formed.

Reactions of lacunary POMs with different magnetic centers such as transition metals, lanthanides, mixed $3 \mathrm{~d}-4 \mathrm{f}$ clusters, or polynuclear transition-metal clusters have resulted in a plethora of structures with variable magnetic behaviors. The magnetic properties of POMs incorporating paramagnetic $3 \mathrm{~d}$ metals such as $\mathrm{Mn}, \mathrm{Fe}, \mathrm{Co}, \mathrm{Ni}$, and $\mathrm{Cu}$ have been widely studied. In comparison, chromium-containing POMs are far less explored, mainly due to the kinetic inertness of the hexaaquachromium(III) cation toward ligand exchange in solution \{cf. section Aquacomplexes of chromium(III) $\}$.

The interaction of a lacunary POM with paramagnetic $\mathrm{Cr}^{\mathrm{III}}$ led to the first example of a chromium-containing polyoxotungstate [9]. In $\mathrm{K}_{3} \mathrm{H}\left[\mathrm{Cr}_{3}(\mathrm{OH})_{3}\left(\mathrm{H}_{2} \mathrm{O}\right)_{3}\right.$-A- $\alpha$ $\mathrm{SiO}_{4} \mathrm{~W}_{9} \mathrm{O}_{30}$ ] three $\mathrm{Cr}^{\mathrm{III}}$ centers are bridged by three hydroxogroups which are fixed on the trivacent tungsten sites in $\left[\mathrm{A}-\alpha-\mathrm{SiO}_{4} \mathrm{~W}_{9} \mathrm{O}_{30}\right]^{10-}$. Further condensation of the compound in aqueous solution led to a sandwich-type dimer containing three paramagnetic $\mathrm{Cr}^{\mathrm{III}}$ ions $\left[\left\{\mathrm{Cr}_{3}(\mathrm{OH})_{3} \mathrm{SiO}_{4} \mathrm{~W}_{9} \mathrm{O}_{30}\right\}_{2}(\mathrm{OH})_{3}\right]^{11-}[10]$. Subsequently, the dinuclear polyanion $\left[\mathrm{Cr}_{2}(\mathrm{OH})\left(\mathrm{OOCCH}_{3}\right)_{2}\left(\mathrm{H}_{2} \mathrm{O}\right)_{2} \mathrm{SiO}_{4}\right.$ $\left.\mathrm{W}_{10} \mathrm{O}_{32}\right]^{5-}$ was synthesized, in which the two $\mathrm{Cr}^{\mathrm{III}}$ centers are bridged by two acetato and a hydroxo group [11]. The tri-chromium-containing polyanion $\left[\left\{\mathrm{Cr}(\mathrm{OH})\left(\mathrm{H}_{2} \mathrm{O}\right)\right\}_{3}\right.$ $\left.\left(\mathrm{SiO}_{4} \mathrm{~W}_{10} \mathrm{O}_{32}\right)_{2}\right]^{10-}$ with a $\left\{\mathrm{Cr}_{3}\right\}$ core has also been described [12].
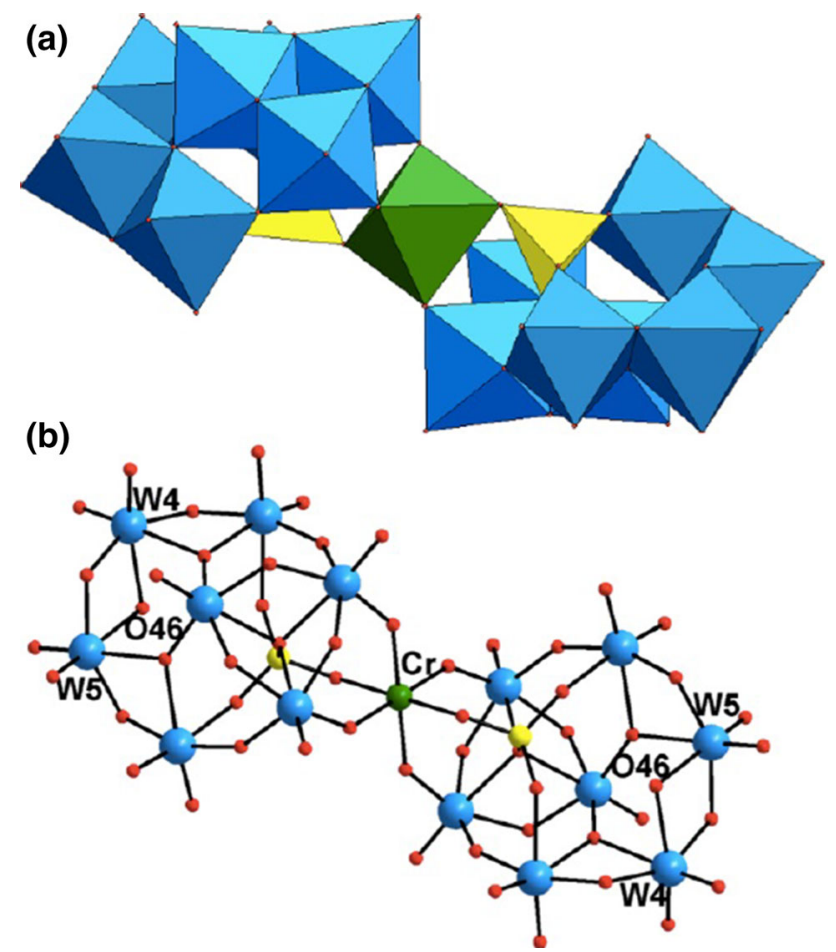

Fig. 24 Polyhedral (a) and ball-and-stick (b) representation of $\left[\mathrm{Cr}\left(\mathrm{HXW}_{7} \mathrm{O}_{28}\right)_{2}\right]^{13-}$ [13]. Color code: $\mathrm{X}=\mathrm{P}^{\mathrm{V}}, \mathrm{As}^{\mathrm{V}}$ (yellow), $\mathrm{W}$ (blue), Cr (green), O (red)

For the first time, two mono-Cr(III)-containing polyoxotungstates, $\mathrm{Na}_{13}\left[\mathrm{Cr}\left(\mathrm{HP}^{\mathrm{V}} \mathrm{W}_{7} \mathrm{O}_{28}\right)_{2}\right] \cdot 47 \mathrm{H}_{2} \mathrm{O}$ and $\mathrm{Na}_{13}\left[\mathrm{Cr}\left(\mathrm{HAs}^{\mathrm{V}} \mathrm{W}_{7} \mathrm{O}_{28}\right)_{2}\right] \cdot 52 \mathrm{H}_{2} \mathrm{O}$, have been prepared via one-pot reactions of the composing elements in $\mathrm{pH} 8$ sodium acetate medium [13]. Both compounds were fully characterized in the solid state by single-crystal X-ray diffraction (cf. Fig. 24), IR spectroscopy, thermogravimetric and elemental analysis, magnetic susceptibility, and EPR measurements. Magnetic studies demonstrated that both compounds exhibit appreciable deviation from typical paramagnetic behavior, and have a ground state $S=3 / 2$, as expected for a $\mathrm{Cr}^{\mathrm{III}}$ ion, but with an exceptionally large zero-field uniaxial anisotropy parameter D.

Coordination of chromium(VI)

At high $\mathrm{pH}$ values chromium(VI) can be coordinated only with the oxide ion, $\mathrm{O}^{2-}$ (cf. Fig. 19). However, due to geometric restrictions $\mathrm{Cr}^{\mathrm{VI}}$ cannot be coordinated with six $\mathrm{O}^{2-}$. Therefore, the coordination number is reduced to four; the yellow monochromate anion, $\mathrm{CrO}_{4}{ }^{2-}$, is formed. At lower $\mathrm{pH}$ its protonation results in the formation of the hydrogen monochromate anion, $\left[\mathrm{O}_{3} \mathrm{CrOH}\right]^{-}$

$\mathrm{CrO}_{4}^{2-}+\mathrm{H}^{+} \rightleftarrows\left[\mathrm{O}_{3} \mathrm{CrOH}\right]^{-}$. 
Fig. 25 Monochromate anion
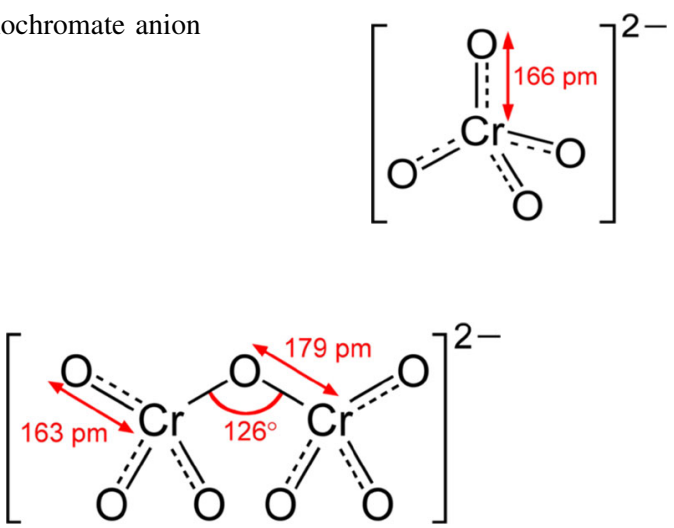

Fig. 26 Dichromate anion

A subsequent condensation reaction

$2\left[\mathrm{O}_{3} \mathrm{CrOH}\right]^{-} \rightleftarrows \mathrm{Cr}_{2} \mathrm{O}_{7}^{2-}+\mathrm{H}_{2} \mathrm{O}$

leads to the stable orange-colored dichromate ion $\mathrm{Cr}_{2} \mathrm{O}_{7}{ }^{2-}$.

The distinct tendency of $\left[\mathrm{O}_{3} \mathrm{CrOH}\right]^{-}$to form $\mathrm{Cr}_{2} \mathrm{O}_{7}{ }^{2-}$ by a condensation reaction can be explained by the high acidity of the monomeric anion, caused by the adjacent hexavalent chromium. Furthermore, the condensation is connected with an entropy gain. The equilibrium between $\mathrm{CrO}_{4}{ }^{2-}$ and $\mathrm{Cr}_{2} \mathrm{O}_{7}{ }^{2-}$ depends on $\mathrm{pH}$ and chromium concentration. The monochromate anion (Fig. 25) is predominant in alkaline $(\mathrm{pH}>6)$, the dichromate anion (Fig. 26) in acidic solutions (pH 2-6). By adding concentrated sulfuric acid to dichromates, 'chromic acid' is formed (cf. section Further applications).

\section{Selected redox reactions}

\section{Breathalyzer}

Breath analyzers do not directly measure the blood alcohol content (BAC), which requires the analysis of a blood sample. Instead, they estimate BAC indirectly by measuring the amount of alcohol in one's breath. Analyzers generally use infrared spectrophotometers, electrochemical fuel cells, or their combination.

The 'Breathalyzer' uses a redox reaction between ethanol, $\mathrm{CH}_{3} \mathrm{CH}_{2} \mathrm{OH}$, and potassium dichromate, $\mathrm{K}_{2} \mathrm{Cr}_{2} \mathrm{O}_{7}$. A breath sample is bubbled through an aqueous solution of potassium dichromate, sulfuric acid, and silver nitrate. Ethanol is oxidized to acetaldehyde, $\mathrm{CH}_{3} \mathrm{CHO}$, while $\mathrm{Cr}^{\mathrm{VI}}$ is reduced to $\mathrm{Cr}^{\mathrm{III}}$. For balancing this redox equation, only the species (molecules and ions) are taken into account which are participants of the chemical reaction. The charge of the ions provides additional assistance with finding the correct stoichiometric numbers.

$$
\begin{aligned}
& 3 \mathrm{CH}_{3} \mathrm{CH}_{2} \mathrm{OH}+\mathrm{Cr}_{2} \mathrm{O}_{7}^{2-}+8 \mathrm{H}^{+} \\
& \quad \rightarrow 3 \mathrm{CH}_{3} \mathrm{CHO}+2 \mathrm{Cr}^{3+}+7 \mathrm{H}_{2} \mathrm{O}
\end{aligned}
$$

During the reaction, the orange dichromate ion changes color to the dark green $\left[\mathrm{CrCl}_{2}\left(\mathrm{OH}_{2}\right)_{4}\right]^{+}$. The degree of color change is directly related to the level of alcohol in the expelled air. To determine the amount of alcohol, the reacted mixture is compared to a vial of unreacted mixture in the photocell system.

The BACtrack ${ }^{\circledR}$ Mobile Breathalyzer connects to an iPhone wirelessly via Bluetooth. This device quickly and easily estimates the BAC using a highly accurate professional-grade alcohol sensor. By connecting to the iPhone, the free BACtrack ${ }^{\circledR}$ app can save the results, estimate when the BAC will return to $0.00 \%$, and provide sharing capabilities. More information is provided at http://www. bactrack.com/mobile and https://www.youtube.com/watch? $\mathrm{v}=\mathrm{gVy}$ ViCBYNRQ.

How a dead drunk guy failed a breathalyzer test can also be watched: www.youtube.com/watch?v=y7iEh7TBGiE.

Chemical volcano

Ammonium dichromate, $\left(\mathrm{NH}_{4}\right)_{2} \mathrm{Cr}_{2} \mathrm{O}_{7}$ (oxidation state of chromium +6 ), is an orange-colored crystalline substance. Because the oxidation state of the nitrogen atom in ammonia is -3 , ammonium dichromate is an unstable and reactive compound that decomposes easily. The same conclusion can be made in case of other ammonium salts like ammonium nitrate, ammonium perchlorate or ammonium chlorate. In all these cases, the anion has an atom in a high oxidation state which is capable to oxidize the nitrogen atom. In the case of ammonium dichromate, nitrogen is oxidized to elemental nitrogen, while chromium is being reduced to the trivalent state:

$$
\begin{gathered}
\left(\mathrm{NH}_{4}\right)_{2} \mathrm{Cr}_{2} \mathrm{O}_{7}(\mathrm{~s}) \rightarrow \mathrm{Cr}_{2} \mathrm{O}_{3}(\mathrm{~s})+\mathrm{N}_{2}(\mathrm{~g})+4 \mathrm{H}_{2} \mathrm{O}(\mathrm{g}) \\
\Delta \mathrm{H}^{\circ}=-325.6 \mathrm{~kJ} \mathrm{~mol}^{-1}
\end{gathered}
$$

A chemical volcano (Fig. 27; Website of Oregon State University: Volcano World) can be watched on YouTube.

On January 19, 1986, The New York Times reported that two workers had been killed and 14 others injured at Diamond Shamrock Chemicals, Ohio, when $900 \mathrm{~kg}$ of $\left(\mathrm{NH}_{4}\right)_{2} \mathrm{Cr}_{2} \mathrm{O}_{7}$ exploded as it was being dried in a heater.

\section{Applications of metallic chromium and its compounds}

The main field of application of chromium is Ferrochrome with $95.2 \%$. Other applications have only low-volume uses: foundry $2.4 \%$, chemicals $1.6 \%$, refractory $0.8 \%$. 
Fig. 27 Chemical volcano (http://www.youtube.com/ watch?v=DD6uh01X7Gg)
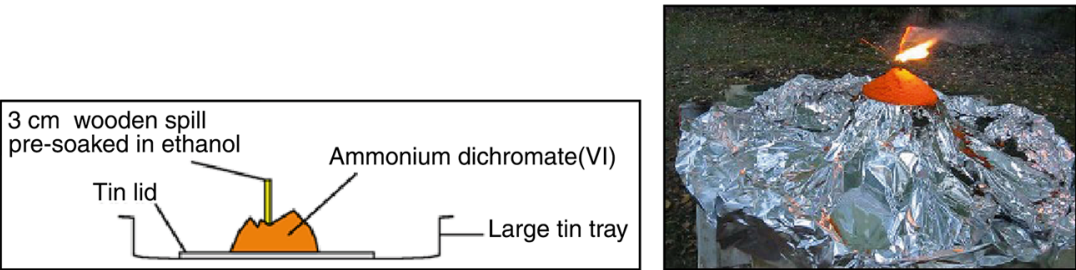

\section{Metallurgy}

Chromium is characterized by its high-corrosion resistance and hardness. A major development was the discovery that steel could be made highly resistant to corrosion and discoloration by adding chromium to form stainless steel. This application, along with chromium electroplating is currently the highest volume uses of the metal. Chromium and ferrochromium are produced from the ore chromite (cf. section Aluminothermic reduction).

Chromium carbides are materials of great technical importance. In the $\mathrm{Cr}-\mathrm{C}$ phase diagram, three carbides with the compositions $\mathrm{Cr}_{3} \mathrm{C}_{2}, \mathrm{Cr}_{7} \mathrm{C}_{3}$ and $\mathrm{Cr}_{23} \mathrm{C}_{6}$ exist (cf. also section Carbothermic reduction). $\mathrm{Cr}_{3} \mathrm{C}_{2}$ is used as an additive in the manufacturing of $\mathrm{WC}-\mathrm{Co}$ hardmetals, acting as a very effective grain growth inhibitor [14]. $\mathrm{Cr}_{3} \mathrm{C}_{2}$ as a basic carbide for hardmetals is the only one of the three chromium carbides of importance. Besides WC, it is frequently used in the preparation of thermally sprayed coatings [15]. The carbothermal reaction of $\mathrm{Cr}_{2} \mathrm{O}_{3}$ with different types of carbon (carbon black, active carbon and graphite) was investigated by micro- and lab-scale methods [16]. The stoichiometric mixtures were calculated for the formation of $\mathrm{Cr}_{3} \mathrm{C}_{2}$ according to

$$
3 \mathrm{Cr}_{2} \mathrm{O}_{3}+13 \mathrm{C} \rightarrow 2 \mathrm{Cr}_{3} \mathrm{C}_{2}+9 \mathrm{CO} \text {. }
$$

Carbon black was found as the carbon type with the highest reactivity. Pronounced grain growth is characteristic for reaction temperature above $1,200{ }^{\circ} \mathrm{C}$ (cf. section Thermodynamic calculations).

Electrolytic production of chromium in the lab

1. 'Chromic acid' (cf. section Further applications) is mixed with deionized water to form a solution having a concentration of $250 \mathrm{~g} \mathrm{~L}^{-1}$. Sulfuric acid is added to the solution to keep the $\mathrm{SO}_{4}{ }^{2-}$ concentration level at $2.5 \mathrm{~g} \mathrm{~L}^{-1}$.

2. The prepared solution is fed to an electrolytic cell. The cell is made of PVC (polyvinyl chloride) with FRP (fiber-reinforced polymer) lining having a $\mathrm{Pb}-\mathrm{Ag}$ (99:1) alloy anode and a stainless steel cathode. The cell-liquid temperature is maintained at around $39{ }^{\circ} \mathrm{C}$ by circulating cell-liquid through a titanium heat exchanger. The cell voltage and current density are maintained at the appropriate value.

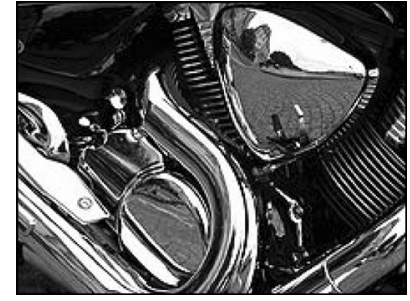

Fig. 28 Decorative chrome plating on a motorcycle

3. After $24 \mathrm{~h}$ cell operation the cathode is taken out of the cell and washed with deionized water. The deposits of chromium from the cathode are peeled off followed by treating with nitric acid to remove adherent impurities, washing with water and finally drying. The dried chromium flakes are used as prepared or ground in a stainless steel ball mill to the desired particle size.

\section{Chromium electroplating}

Chromium surfaces are produced on other metals by electroplating and chromizing. http://www.youtube.com/ watch?v=RJ6j6YjJrHY.

Decorative electroplating (Thickness $0.13-1.3 \mu \mathrm{m}$ ) (Fig. 28) is usually deposited on nickel.

'Hard' plating (Thickness 5-250 $\mu \mathrm{m}$ ) is used because of its wear resistance and low coefficient of friction. For these types of plating, solutions of 'chromic acid' are used.

\section{Pigments and dyes}

Federal law in the United States requires that, in addition to flashing lights and safety devices, school buses must be painted 'school bus yellow'. It is a color which was especially formulated for use on school buses in North America in 1939. The color is now officially known in the US and Canada as 'National School Bus Glossy Yellow' (Fig. 29). Before the standard school bus yellow color was developed, school buses were a pure yellow, closer to the color of a lemon. Scientists have found that people are able to see yellow objects in their peripheral field 1.24 times better than red. Unlike red, yellow is also more easily noticed in a dark environment. The pigment used for this color was for 


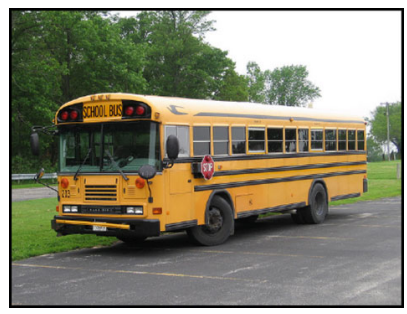

Fig. 29 School bus in the US painted in chrome yellow

a long time 'chrome yellow', lead monochromate, $\mathrm{PbCrO}_{4}$ (Fig. 19). The pigment had been commonly produced by mixing solutions of lead nitrate, $\mathrm{Pb}\left(\mathrm{NO}_{3}\right)_{2}$, and potassium chromate, $\mathrm{K}_{2} \mathrm{CrO}_{4}$, and filtering off the lead chromate precipitate. 'Chrome yellow' does not photo degrade but it tends to darken due to the formation of $\mathrm{Cr}_{2} \mathrm{O}_{3}$.

The use of 'chrome yellow' declined due to environmental and safety concerns. It was replaced by organic pigments or inorganic alternatives free from lead. Niobium Tin Pyrochlore (NTP), $\mathrm{Sn}_{2} \mathrm{Nb}_{2} \mathrm{O}_{7}$, is a patented (US $8,192,541$ ) pigment that offers outstanding bright and opaque masstones and clean tints. It is the first high-performance alternative to have the coloristic and weathering performance to provide a viable replacement for lead chromate in wide selection of demanding applications (http://www.shepherdcolor.com/Products/NTP-Yellow/).

The composition of the mineral pyrochlore can be described by the formula sodium calcium niobium oxide hydroxide fluoride, $(\mathrm{Na}, \mathrm{Ca})_{2} \mathrm{Nb}_{2} \mathrm{O}_{6}(\mathrm{O}, \mathrm{OH}, \mathrm{F})$. However, pyrochlore is also a broader term for the pyrochlore crystal structure (space group 227: $\mathrm{Fd}-3 \mathrm{~m}$ ), describing materials of the type $\mathrm{A}_{2} \mathrm{~B}_{2} \mathrm{O}_{6}$ and $\mathrm{A}_{2} \mathrm{~B}_{2} \mathrm{O}_{7}$, where $\mathrm{A}$ and $\mathrm{B}$ are generally rare-earth or transition metals.

'Chrome oxide green' is a mixture of 'Prussian blue' and 'chrome yellow'. 'Prussian blue' is the dark blue pigment iron(III) hexacyanoferrate(II), $\quad \mathrm{Fe}_{4}\left[\mathrm{Fe}(\mathrm{CN})_{6}\right]_{3} \cdot n \mathrm{H}_{2} \mathrm{O}$ ( $n=14-16)$. Another name for the pigment is 'Berlin blue' or, in painting, 'Parisian blue'. 'Turnbull's blue' is the same substance, but is made from different reagents, and its slightly different color stems from different impurities. 'Prussian blue' was one of the first synthetic pigments. It is employed as a very fine colloidal dispersion, as the compound itself is not soluble in water.

\section{Wood preservatives}

Because of their toxicity, $\mathrm{Cr}^{\mathrm{VI}}$ salts are used for the preservation of wood. For example, 'Chromated Copper Arsenate' (CCA) is used in timber treatment to protect wood decay from fungi, wood attacking insects, including termites, and marine borers. CCA is known by many trade names, including the brands Tanalith ${ }^{\circledR}$, SupaTimber ${ }^{\circledR}$, and Celcure ${ }^{\circledR}$. Chromium (Sodium dichromate dihydrate,
Table 3 Three formulations of 'chromated copper arsenate'

\begin{tabular}{llll}
\hline \multicolumn{4}{l}{ Composition of CCA-Type A, B, and C } \\
\hline Oxides & CCA-Type A (\%) & CCA-Type B (\%) & CCA-Type C (\%) \\
\hline $\mathrm{CrO}_{3}$ & 65.5 & 35.3 & 47.5 \\
$\mathrm{CuO}$ & 18.1 & 19.6 & 18.5 \\
$\mathrm{As}_{2} \mathrm{O}_{5}$ & 16.4 & 45.1 & 34.0 \\
\hline
\end{tabular}

$\mathrm{Na}_{2} \mathrm{Cr}_{2} \mathrm{O}_{7} \cdot 2 \mathrm{H}_{2} \mathrm{O}$, or potassium dichromate, $\mathrm{K}_{2} \mathrm{Cr}_{2} \mathrm{O}_{7}$ ) acts as a chemical fixing agent to the wood's cellulose and lignin and has little or no preserving properties. Copper (Copper(II) sulfate pentahydrate, $\mathrm{CuSO}_{4} \cdot 5 \mathrm{H}_{2} \mathrm{O}$ ) acts primarily to protect the wood against decay, fungi and bacteria. Arsenic (Arsenic acid hemihydrate, $\mathrm{H}_{3} \mathrm{AsO}_{4} \cdot 1 / 2 \mathrm{H}_{2} \mathrm{O}$ ) is the main insecticidal component of CCA. The 'American Wood Preservers Association' (AWPA) has standardized the formulations of CCA compositions for greater ease into a uniform nomenclature based on the oxides $\mathrm{CrO}_{3}, \mathrm{CuO}$ and $\mathrm{As}_{2} \mathrm{O}_{5}$ (Table 3). The formulations are prepared and sold as solutions containing from about $45-75 \%$ active oxides in water. The concentrated solutions are then diluted to about $1-10 \%$ active oxides for use in treating wood (http://www. google.com/patents/US3957494).

\section{Tanning}

Chromium(III) salts, especially potassium chromium(III) sulfate dodecahydrate (chromium alum), $\mathrm{KCr}\left(\mathrm{SO}_{4}\right)_{2} \cdot 12 \mathrm{H}_{2} \mathrm{O}$ (Fig. 30), and chromium(III) sulfate dodecahydrate, $\mathrm{Cr}_{2}\left(\mathrm{SO}_{4}\right)_{3} \cdot 12 \mathrm{H}_{2} \mathrm{O}$, are used in the tanning of leather. Alum is both a specific chemical compound and a class of compounds. The specific compound is potassium aluminum sulfate dodecahydrate (potassium alum), $\mathrm{KCr}\left(\mathrm{SO}_{4}\right)_{2} \cdot 12 \mathrm{H}_{2} \mathrm{O}$. More widely, alums are double sulfate salts, with the general formula $\mathrm{A}_{2}\left(\mathrm{SO}_{4}\right) \cdot \mathrm{M}_{2}\left(\mathrm{SO}_{4}\right)_{3} \cdot 24 \mathrm{H}_{2} \mathrm{O}$, where $\mathrm{A}$ is a monovalent cation such as potassium or ammonium and $\mathrm{M}$ is a trivalent metal ion such as aluminum or chromium(III).

Chromium(III) stabilizes the leather by cross linking the collagen fibers. Chromium-tanned leather contains between 4 and $5 \%$ of chromium, which is tightly bound to the proteins. Although the form of chromium used for tanning is not the toxic hexavalent variety, there remains interest in use of less chromium to better manage chromium in tanning.

A chrome tanning process which allows the reuse of tanning floats has been developed. The most commonly used chromium salts were replaced by highly masked and basified ones. This substitution eliminates basification operation and prevents $\mathrm{pH}$ change and the considerable neutral salts concentration increase in the tanning float. Consequently, tanning float can be reused several times. An optimum chromium salt concentration in the tanning 
Fig. 30 Examples of chromium alum crystals

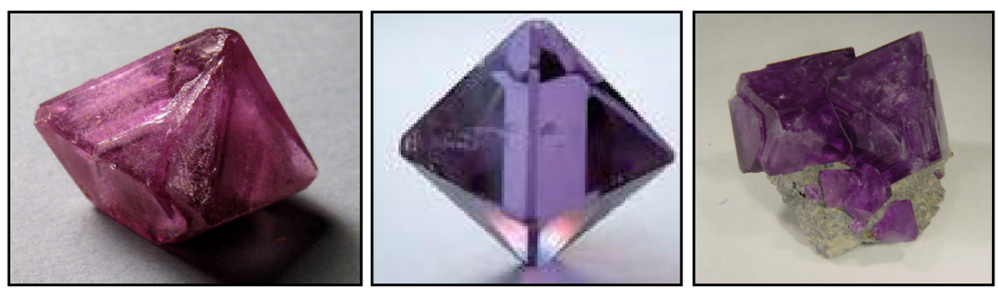

float between 10 and $12.5 \%$ has been determined. It has been shown that the number of times the tanning float can be reused depends on the quality of the leather grain to be manufactured. At best, $18 \mathrm{~L}$ of water per kilogram of tanned leather can be saved, which results in savings of $90 \%$ of water normally used [17].

\section{Foundry (Refractory materials)}

The high heat resistivity and high melting point makes chromite, $\mathrm{FeCr}_{2} \mathrm{O}_{4}\left(2,190-2,270{ }^{\circ} \mathrm{C}\right)$, and chromium(III) oxide, $\mathrm{Cr}_{2} \mathrm{O}_{3}\left(2,435{ }^{\circ} \mathrm{C}\right)$ components for high-temperature refractory applications, like blast furnaces, cement kilns, molds for the firing of bricks and as foundry sands for the casting of metals. In these applications, the refractory materials are made from mixtures of chromite and magnesite, $\mathrm{MgCO}_{3}$. The use is declining because of the environmental regulations due to the possibility of the formation of $\mathrm{Cr}^{\mathrm{VI}}$.

\section{Catalysis}

Several chromium compounds are used as catalysts for processing hydrocarbons.

A common catalyst for production of polyethylene is the 'Phillips catalyst', prepared by depositing chromium(VI) oxide, $\mathrm{CrO}_{3}$ (cf. section Further applications), on silica, $\mathrm{SiO}_{2}$. Fe-Cr mixed oxides are employed as high-temperature catalysts for the 'water gas shift reaction'

$\mathrm{CO}(\mathrm{g})+\mathrm{H}_{2} \mathrm{O}(\mathrm{v}) \rightarrow \mathrm{CO}_{2}(\mathrm{~g})+\mathrm{H}_{2}(\mathrm{~g})$.

Copper chromite, $\mathrm{Cu}_{2} \mathrm{Cr}_{2} \mathrm{O}_{5}$ (often containing barium oxide, $\mathrm{BaO}$ ), is a useful hydrogenation catalyst.

\section{Interconnectors for SOFC}

A 'Solid Oxide Fuel Cell' (SOFC) is an electrochemical conversion device that produces electricity directly from oxidizing a fuel (Scheme 1). Fuel cells are characterized by their electrolyte material. The SOFC has a solid oxide or ceramic electrolyte. Advantages of this class of fuel cells include high efficiency, long-term stability, fuel flexibility, low emissions, and relatively low cost. The major disadvantage is the high operating temperature, which results in

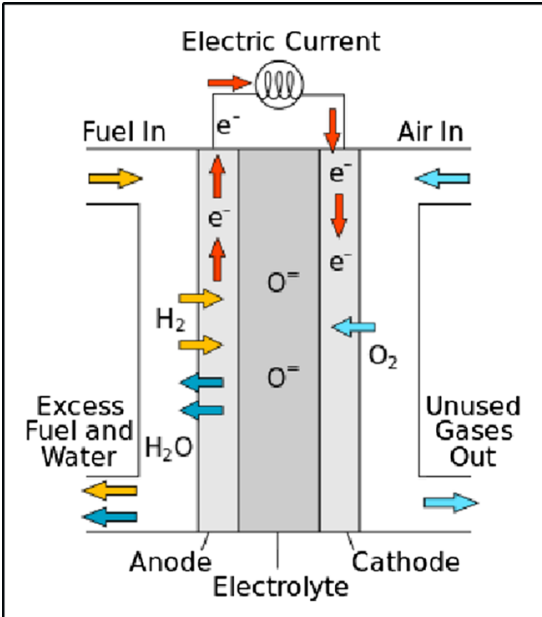

Scheme 1 Solid oxide fuel cell

longer start-up times and mechanical and chemical compatibility issues.

The 'interconnector' can be either a metallic or ceramic layer that sits between each individual cell. Its purpose is to connect each cell in series, so that the electricity each cell generates can be combined. Because the interconnector is exposed to both the oxidizing and reducing side of the cell at high temperatures, it must be extremely stable. Therefore, ceramics have been more successful in the long-term than metals as interconnector materials. However, these ceramic interconnector materials are very expensive as compared to metals. The material of choice for an interconnector is the metallic alloy CFY (Cr-Fe-Y), a chromium-based alloy with $5 \%$ iron (Fig. 31). The coefficient of expansion of CFY is precisely adapted to that of the electrolyte in the fuel cell. At operating temperatures of up to $850{ }^{\circ} \mathrm{C}$, the corrosion resistance of the chosen material is a crucial factor. In particular, the CFY interconnector must withstand aerial oxygen and a high hydrogen concentration.

\section{Further applications}

Chromium(IV) oxide, $\mathrm{CrO}_{2}$, is a black synthetic magnetic solid. It once was widely used in magnetic tape emulsion. With the increasing popularity of CDs and DVDs, the use of $\mathrm{CrO}_{2}$ has declined. However, it is still used in data tape 
Fig. 31 Interconnector $\mathrm{CFY}$ (http://www.plansee.com/en/ Materials-Chromium-939.htm)
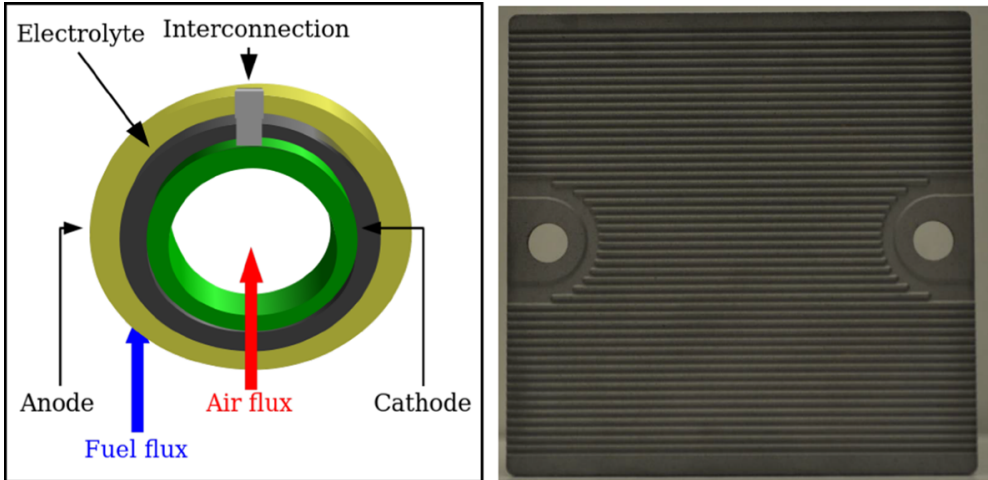

applications for enterprise-class storage systems and is considered by numerous oxide and tape manufacturers to have been one of the best magnetic recording particulates ever invented.

$\mathrm{CrO}_{2}$ was first prepared by Friedrich Wöhler (1800 1882) through decomposition of chromyl chloride, $\mathrm{CrO}_{2} \mathrm{Cl}_{2} \cdot \mathrm{CrO}_{2}$ adopts the rutile structure, as do many metal dioxides. As such each $\mathrm{Cr}^{\mathrm{IV}}$ center has octahedral coordination geometry and each oxide is trigonal planar (Fig. 32).

The manufacture of $\mathrm{CrO}_{2}$ was patented in 1966 (US 3,278263A) by Norman L. Cox, a chemist at E.I. DuPont. The oxidation of $\mathrm{Cr}_{2} \mathrm{O}_{3}$ with $\mathrm{CrO}_{3}$ under hydrothermal conditions at $530{ }^{\circ} \mathrm{C}$ and a pressure of $200 \mathrm{MPa}$ generated $\mathrm{CrO}_{2}$. The balanced equation is

$\mathrm{Cr}_{2} \mathrm{O}_{3}+3 \mathrm{CrO}_{3} \rightarrow 5 \mathrm{CrO}_{2}+\mathrm{O}_{2}$.

When commercialized in the late 1960s as a recording medium, DuPont assigned it the trade name Magtrieve ${ }^{\mathrm{TM}}$.

Chromates can prevent corrosion of steel under wet conditions, and therefore chromates are added to drilling muds. $\mathrm{Cr}_{2} \mathrm{O}_{3}$ is a metal polish known as green rouge.

The term 'chromic acid' is usually used for a mixture made by adding concentrated sulfuric acid to sodium or potassium dichromate. The mixture contains a variety of compounds, including solid chromium trioxide, $\mathrm{CrO}_{3}$. It consists of infinite chains of $\mathrm{CrO}_{4}$-tetrahedra that share vertices. Each chromium center shares two oxygen atoms with neighbors, while two other oxygen atoms are not shared, giving an overall stoichiometry of 1:3 (Fig. 33).

In the past, chromic acid was widely used as a powerful oxidizing agent for cleaning laboratory glassware of any trace of otherwise insoluble organic residues. This application has been banned in most institutions due to serious health concerns. Hexavalent chromium compounds (including chromic acid, chromates, chlorochromates) are toxic and carcinogenic. Chromic acid mist is a severe irritant of the nasopharynx, larynx, lungs and skin. More health hazard information about chromium is given in the following section Biological role of chromium and environmental concerns.

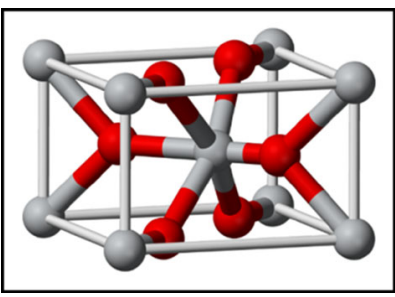

Fig. 32 Unit cell of $\mathrm{CrO}_{2}$; $\mathrm{Cr}$ atoms-gray, $\mathrm{O}$ atoms-red

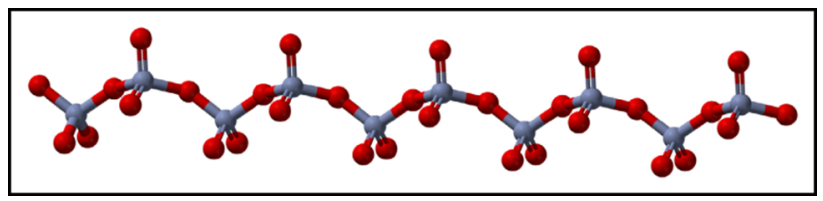

Fig. 33 Ball-and-stick representation of $\mathrm{CrO}_{3}$

\section{Biological role of chromium and environmental concerns}

The review [18] summarizes the existing knowledge about the mechanisms of biologically relevant redox reactions of $\mathrm{Cr}^{\mathrm{VI} / \mathrm{V} / \mathrm{IV} / \mathrm{III}}$ complexes. The application of kinetic analysis techniques in conjunction with methods for characterization of reactive intermediates such as X-ray absorption spectroscopy (XAS), Electrospray ionization mass spectrometry (ESI-MS), and Electron paramagnetic resonance spectroscopy (EPR), for understanding the chemical basis of chromium's biological activities, are being illustrated. Cellular uptake of $\mathrm{Cr}^{\mathrm{VI}}$, followed by its reduction to $\mathrm{Cr}^{\mathrm{III}}$ with the formation of reactive $\mathrm{Cr}^{\mathrm{V} / \mathrm{IV}}$ intermediates, is a generally accepted cause of $\mathrm{Cr}^{\mathrm{VI}}$-induced genotoxicity and carcinogenicity. Recently, $\mathrm{Cr}^{\mathrm{III}}$ oxidation to $\mathrm{Cr}^{\mathrm{V}}$ and/or $\mathrm{Cr}^{\mathrm{VI}}$ in biological systems came into consideration as a possible reason of anti-diabetic activities of some $\mathrm{Cr}^{\mathrm{III}}$ complexes, as well as of long-term toxicities of such complexes [18].

Water-insoluble $\mathrm{Cr}^{\mathrm{III}}$ compounds and chromium metal are not considered a health hazard, while the toxicity and carcinogenic properties of $\mathrm{Cr}^{\mathrm{VI}}$ have been known for a long 
time. $\mathrm{Cr}^{\mathrm{VI}}$ has not been established as a carcinogen when in solution, although it may cause allergic contact dermatitis (ACD). Chromium has no verified biological role and has been classified as not essential for mammals. The use of chromium-containing dietary supplements is controversial owing to the absence of any verified biological role. In the United States, the dietary guidelines for daily chromium uptake were lowered from 50 to $200 \mu \mathrm{g}$ for an adult to $35 \mu \mathrm{g}$ (adult male) and $25 \mu \mathrm{g}$ (adult female). Recent reviews suggest that moderate uptake of $\mathrm{Cr}^{\mathrm{III}}$ through dietary supplements poses no risk.

Inhalation of water-soluble $\mathrm{Cr}^{\mathrm{VI}}$ salts may result in substantial systemic absorption. Metallic chromium and $\mathrm{Cr}^{\mathrm{II}}$ of $\mathrm{Cr}^{\mathrm{III}}$ salts are absorbed minimally after inhalation. Ingested $\mathrm{Cr}^{\mathrm{VI}}$ salts are converted by gastric juice to $\mathrm{Cr}^{\mathrm{III}}$ prior to absorption. The extent of absorption varies with the particular salt ingested and the circumstances of ingestion. $\mathrm{Cr}^{\mathrm{VI}}$ salts generally are absorbed well topically through intact skin. $\mathrm{Cr}^{\mathrm{VI}}$ can penetrate the skin and be transformed to $\mathrm{Cr}^{\mathrm{III}}$ which becomes a hapten and part of the allergic reaction.

Contact with textiles colored with chromate-based pigments can be sufficient to exacerbate dermatitis. Wearing of leather shoes tanned with chromates can produce dermatitis of the feet. 'Housewife eczema' may be largely a chromate sensitivity phenomenon, as some detergents and bleaches contain more than trace amounts of chromate salts. The optimal treatment for chromium toxicity lies in its prevention, with the use of appropriate industrial hygiene practices, of proper workplace controls and good personal hygiene measures.

$\mathrm{Cr}^{\mathrm{VI}}$ compounds are widely-used industrial chemicals and are recognized human carcinogens. The mechanisms of carcinogenesis associated with these compounds remain to be investigated. A study focused on dose-dependence of $\mathrm{Cr}^{\mathrm{VI}}$-induced uptake and cellular responses. The results show that $\mathrm{Cr}^{\mathrm{VI}}$ is able to enter the cells at low concentration $(<10 \mathrm{M})$ and that the $\mathrm{Cr}^{\mathrm{VI}}$ uptake appears to be a combination of saturable transport and passive diffusion. The results may guide further research to better understand and evaluate the risk of $\mathrm{Cr}^{\mathrm{VI}}$-induced carcinogenesis at low levels of exposure [19].

Chronic occupational exposure to hexavalent chromium causes DNA damage in electroplating workers. The findings of the study indicated that there were higher levels of occupational chromium exposure and detectable DNA damage in electroplating workers. DNA damage was associated with the chromium level in erythrocytes, which may serve as a useful biomarker for hexavalent chromium [20].

The movie Erin Brockovich, directed by Steven Soderbergh, is a dramatization of the true story of Erin Brockovich, portrayed by Julia Roberts, who for her performance won the OSCAR as Best Actress at the 72rd Academy Awards in 2001.

At the center of the case was a facility, built in 1952 as part of a natural-gas pipeline, in the Southern California town of Hinkley. Between 1952 and 1966, Pacific Gas and Electric Company (PG\&E) used hexavalent chromium to fight corrosion in the cooling tower of a compressor station. The wastewater dissolved the hexavalent chromium from the cooling towers and was discharged to unlined ponds at the site. Some of the wastewater percolated into the groundwater, affecting the town of Hinkley. Erin Brockovich, an unemployed single mother, became a legal assistant and almost single-handedly brought down PG\&E accused of polluting the city's water supply. She was digging into the case and found evidence that the groundwater in Hinkley was seriously contaminated with carcinogenic hexavalent chromium, but PG\&E had been telling Hinkley residents that they used a safer form of chromium. The case was settled in 1996 for 333 million dollars, the largest settlement ever paid in a direct-action lawsuit in US history. Brockovich's attorneys cashed in 133.6 million dollars of that settlement. Brockovich herself received a bonus of 2 million dollars.

As chromium compounds were used in dyes and paints and the tanning of leather, these compounds are often found in soil and groundwater at abandoned industrial sites, now needing environmental cleanup and remediation. Primer paint containing hexavalent chromium is still widely used for aerospace and automobile refinishing applications. In 2010, the 'Environmental Working Group' (EWG) studied the drinking water in 35 American cities. The study found measurable hexavalent chromium in the tap water of 31 of the cities sampled, with Norman/ Oklahoma, at the top of the list. Concentrations of $\mathrm{Cr}^{\mathrm{VI}}$ in US municipal drinking water supplies reported by EWG are within likely natural background levels for the areas tested and not necessarily indicative of industrial pollution.

Acknowledgments The author is indebted to Prof. Dr. Fritz Scholz for his invaluable discussions and stimulating ideas.

\section{References}

1. Goldschmidt H (1895) Verfahren zur Herstellung von Metallen oder Metalloiden oder Legierungen derselben (Process for the production of metals or metalloids or alloys of the same), Deutsches Reichspatent (D.R.P.) no. 96317

2. Antony MP, Mathews CK, Vidhya R, Varada Raju UV (1995) Thermochim Acta 262:145-155

3. Mori T, Yang J, Kuwabara M (2007) ISIJ Int 47:1387-1393

4. Tytko KH (1979) Chem unserer Zeit 13:184-194

5. Marczak S, Wrona PK (1988) J Electroanal Chem 247:215-227 
6. Altman C, King EL (1961) J Amer Chem Soc 83:2825-2830

7. Boeyens JCA (2005) New theories for chemistry. Elsevier, Amsterdam

8. Huheey JE, Keiter EA, Keiter RL (2014) Anorganische Chemie -Prinzipien von Struktur und Reaktivität. Walter de Gruyter GmbH, Berlin/Boston, pp 967-984

9. Wassermann K, Lunk HJ, Palm R, Fuchs J (1994) Acta Cryst C50:348-350

10. Wassermann K, Palm R, Lunk HJ, Fuchs J, Steinfeld N, Stößer R (1995) Inorg Chem 34:5029-5036

11. Wassermann K, Lunk HJ, Palm R, Fuchs J, Steinfeld N, Stößer R, Pope M (1995) Inorg Chem 35:3273-3279

12. Compain JD, Mialane P, Dolbecq A, Mbomekallé IM, Marrot J, Sécheresse F, Duboc C, Rivière E (2010) Inorg Chem 49:28512858

13. Liu W, Christian JH, Al-Oweini R, Bassil BS, van Tol J, Atanasov M, Neese F, Dalal NS, Kortz U (2014) Inorg Chem 53:9274-9283
14. Pierson HO (1996) Handbook of refractory carbides and nitrides: properties, characteristics, processing and applications. Noyes, Westwood, NJ

15. Zackrisson J, Jansson B, Upadhyaya GS, Andrén HO (1998) Int J Refract Met Hard Mater 16:417-422

16. Berger LM, Stolle S, Gruner W, Wetzig K (2001) Int J Refract Met Hard Mater 19:109-121

17. Morera JM, Bartolí E, Chico R, Solé C, Cabeza LF (2011) Online Vers J Clean Prod 19:2128-2132

18. Levina A, Lay PA (2005) Coord Chem Rev 249:281-298

19. Liu K, Husler J, Ye J, Leonard SS, Cutler D, Chen F, Wang S, Zhang Z, Ding M, Wang L, Shi Z (2001) Mol Cell Biochem 222:221-229

20. Zhang X-H, Zhang X, Wang X-C, Jin L-F, Yang Z-P, Jiang C-X, Chen Q, Ren X-B, Cao J-Z, Wang Q, Zhu Y-M (2011) BMC Public Health 11:224. http://www.biomedcentral.com/14712458/11/224 